\title{
The Pivotal Role of Airway Smooth Muscle in Asthma Pathophysiology
}

\author{
Annaïg Ozier, 1, 2,3 Benoit Allard, 1, 2 Imane Bara,, ${ }^{1,2}$ Pierre-Olivier Girodet, 1, 2, 3 \\ Thomas Trian, ${ }^{1,2}$ Roger Marthan, ${ }^{1,2,3}$ and Patrick Berger ${ }^{1,2,3}$ \\ ${ }^{1}$ Univ. Bordeaux, Centre de Recherche Cardio-Thoracique de Bordeaux, F-33000 Bordeaux, France \\ ${ }^{2}$ INSERM U1045, F-33000 Bordeaux, France \\ ${ }^{3}$ CHU de Bordeaux, Service D'Exploration Fonctionnelle Respiratoire, CIC-P 0005, F-33000 Bordeaux, France
}

Correspondence should be addressed to Patrick Berger, patrick.berger@u-bordeaux2.fr

Received 13 July 2011; Accepted 30 August 2011

Academic Editor: Brian Oliver

Copyright (c) 2011 Annaïg Ozier et al. This is an open access article distributed under the Creative Commons Attribution License, which permits unrestricted use, distribution, and reproduction in any medium, provided the original work is properly cited.

\begin{abstract}
Asthma is characterized by the association of airway hyperresponsiveness (AHR), inflammation, and remodelling. The aim of the present article is to review the pivotal role of airway smooth muscle (ASM) in the pathophysiology of asthma. ASM is the main effector of AHR. The mechanisms of AHR in asthma may involve a larger release of contractile mediators and/or a lower release of relaxant mediators, an improved ASM cell excitation/contraction coupling, and/or an alteration in the contraction/load coupling. Beyond its contractile function, ASM is also involved in bronchial inflammation and remodelling. Whereas ASM is a target of the inflammatory process, it can also display proinflammatory and immunomodulatory functions, through its synthetic properties and the expression of a wide range of cell surface molecules. ASM remodelling represents a key feature of asthmatic bronchial remodelling. ASM also plays a role in promoting complementary airway structural alterations, in particular by its synthetic function.
\end{abstract}

\section{Introduction}

The pathophysiology of asthma is characterized by the association of airway hyperresponsiveness (AHR), inflammation, and remodelling [1-3]. AHR is defined by an increased airway narrowing to a wide range of stimuli and is responsible for recurrent episodes of wheezing and breathlessness. Airway smooth muscle (ASM) is considered as the main cell type involved in AHR $[4,5]$. Bronchial inflammation in asthma involves the recruitment of various inflammatory cells including eosinophils, mast cells and $\mathrm{T}$ lymphocytes [1]. However, the microlocalization of these cell types is different within the asthmatic ASM layer [6], suggesting complex interactions between inflammatory cells and ASM cells. Bronchial remodelling is described as an increased thickening of the bronchial wall due to various structural alterations including epithelial changes [7], subepithelial membrane thickening, enhanced extracellular matrix (ECM) deposition [8], mucous gland and goblet cell hypertrophy and hyperplasia [9], neoangiogenesis [10], and increase in
ASM mass [11, 12]. This latter appears to be a key feature of bronchial remodelling since increased ASM mass is associated with a decrease in lung function in asthma [13-15]. The aim of the present article is thus to review the pivotal role of ASM in the pathophysiology of asthma.

\section{Role of ASM in Airway Hyperresponsiveness}

AHR is usually described as either nonspecific or specific AHR (Table 1). Nonspecific AHR is a common feature of asthma, although it is also found in some patients suffering from chronic obstructive pulmonary disease or allergic rhinitis [16]. Stimuli inducing nonspecific AHR can be direct or indirect (Table 1). Direct mediators stimulate ASM cell membrane receptors. For instance, methacholine activates muscarinic M3 receptor and induces ASM contraction [17]. Conversely, indirect mediators first stimulate one or more intermediary cells, leading to the release of contractile agonists, which, in turns, induce ASM contraction [18]. All of these indirect challenges are associated with the release 
TABLE 1: Stimuli used to assess airway hyperresponsiveness (AHR) in vivo.

\begin{tabular}{|c|c|c|c|}
\hline AHR & Mechanisms & Types & Stimuli \\
\hline \multirow[t]{2}{*}{ Nonspecific } & \multirow[t]{2}{*}{ Direct } & \multirow[t]{2}{*}{ Pharmacological } & $\begin{array}{l}\text { Methacholine } \\
\text { [22] }\end{array}$ \\
\hline & & & Histamine [23] \\
\hline \multirow{4}{*}{ Nonspecific } & \multirow{4}{*}{ Indirect } & \multirow{4}{*}{ Physical } & Exercise [24] \\
\hline & & & $\begin{array}{l}\text { Cold air, dry air } \\
\text { [25] }\end{array}$ \\
\hline & & & $\begin{array}{l}\text { Eucapnic } \\
\text { hyperventilation } \\
{[26]}\end{array}$ \\
\hline & & & $\begin{array}{l}\text { Hypo osmolar } \\
\text { solution [27] }\end{array}$ \\
\hline \multirow[t]{2}{*}{ Nonspecific } & \multirow[t]{2}{*}{ Indirect } & \multirow[t]{2}{*}{ Chemical } & $\begin{array}{l}\text { Adenosine } \\
\text { monophosphate } \\
{[28]}\end{array}$ \\
\hline & & & Mannitol [27] \\
\hline Specific & Indirect & Allergen & $\begin{array}{l}\text { Pollens, House } \\
\text { dust mites [29] }\end{array}$ \\
\hline
\end{tabular}

of mast cell mediators, such as prostaglandins, PGD2 and PGF2 $\alpha$, or histamine, which, respectively, activate ASM cell membrane receptors TP, FP, and H1 [19]. For instance, acute and intense exercise induces airway dehydration, increasing osmolarity of the airway surface liquid [20]. Cell volume shrinkage and restoration release both mast cell mediators and acetylcholine from nerves [20]. On the other hand, specific AHR is limited to allergic asthmatics. In such case, the stimulus is an allergen against which the patient is specifically sensitized. The mechanism of ASM contraction also involves the release of mast cell mediators. Specific AHR measurement is restricted to clinical trials or detection of occupational diseases. Indeed, allergen-specific stimulation can enhance nonspecific AHR [21] and induce a late phase response [19].

The mechanisms of AHR in asthma may involve (i) a larger release of contractile mediators, (ii) a lower release of relaxant mediators, (iii) an improved ASM cell excitation/contraction coupling, and/or (iv) an alteration in the contraction/load coupling.

2.1. Larger Release of Contractile Mediators. The contraction of ASM can be induced by a variety of extracellular messengers, which act through interaction with specific receptors at the site of the plasma membrane of ASM (Table 2). These contractile agonists, either inflammatory mediators or neurotransmitters, are released at high concentrations in asthmatic bronchi, especially regarding mast cell mediators following indirect challenges [19]. For instance, mast cells release tryptase, which increases ASM cells cytosolic calcium concentration [30], allowing them to contract after activation of the protease activated receptor (PAR) type 2, expressed on their membrane [31]. Mast cells, but also eosinophils, produce contractile prostaglandins such as PGF2 $\alpha$, PGD2, and thromboxane TXA2. The concentration of these prostaglandins, and also that of histamine, is
TABLE 2: Contractile and relaxant mediators for ASM.

\begin{tabular}{lll}
\hline Types of mediators & Actions & Stimuli \\
\hline \multirow{4}{*}{ Inflammatory } & & Histamine [23] \\
& Tryptase [42] & Contraction \\
& & Prostanoids (PGF2 $\alpha$, \\
& Cysteinyl leukotrienes \\
& & (LTC4, LTD4, LTE4) [22] \\
& & Endothelin [44] \\
\hline \multirow{3}{*}{ Neurotransmitters } & Contraction & Acetylcholine [45] \\
& & Neurokinine A [46] \\
& & Substance P [46] \\
& & Calcitonin Gene Related \\
& & Peptide [47] \\
\hline \multirow{2}{*}{ Inflammatory } & \multirow{2}{*}{ Relaxation } & Prostanoids (PGE2, PGI2) \\
& & [48] \\
\hline \multirow{2}{*}{ Neurotransmitters } & Relaxation & Adrenaline [49] \\
& & Noradrenaline [50] \\
& & Vasoactive Intestinal \\
& & Peptide [46]
\end{tabular}

increased in asthma [32]. Similarly, inflammatory cells also produce both cysteinyl leukotrienes (LTC4, LTD4, LTE4), which are also very potent direct contractile agonists of ASM [33], and LTB4, which acts indirectly through the release of TXA2 [34]. Such cysteinyl leukotrienes are also increased in asthma [35], as well as endothelin [36], another direct contractile agonist of ASM [37], produced by epithelial cells or endothelial cells [38]. The release of contractile neurotransmitters, acetylcholine or tachykinins, is also known to be higher in asthma $[39,40]$. It is noteworthy that the loss of epithelial barrier integrity commonly associated with asthma may increase exposure of ASM to inhaled contractile agonists [41].

2.2. Lower Release of Relaxant Mediators. AHR may also be related to a lower release of relaxant agonists either neurotransmitters or inflammatory mediators (Table 2). Physiologically, the adrenergic innervation is sparse in the ASM [51]. Moreover, a decreased number of $\beta 2$-adrenergic receptor sometimes associated with its desensitization has been suggested in asthma following chronic medication with short-acting $\beta 2$-agonists [52]. A lower release of adrenaline has also been demonstrated during asthma attacks [53]. The second important relaxing neurotransmitter is the vasoactive intestinal peptide (VIP), which is colocalized with acetylcholine [54]. However, the expression of VIP in the asthmatic ASM is not decreased but surprisingly increased [55]. By contrast, the production of PGE2, which is known to relax ASM, is significantly lower in asthmatic than in nonasthmatic ASM cells [56]. Other cellular sources of PGE2 and other ASM relaxant, such as NO, may also be implicated.

\subsection{Improved ASM Cell Excitation/Contraction Coupling.} Cytokines, such as IL-5 or IL-13, that are both increased in asthma, do not contract ASM per se. In fact, IL-5 induces 


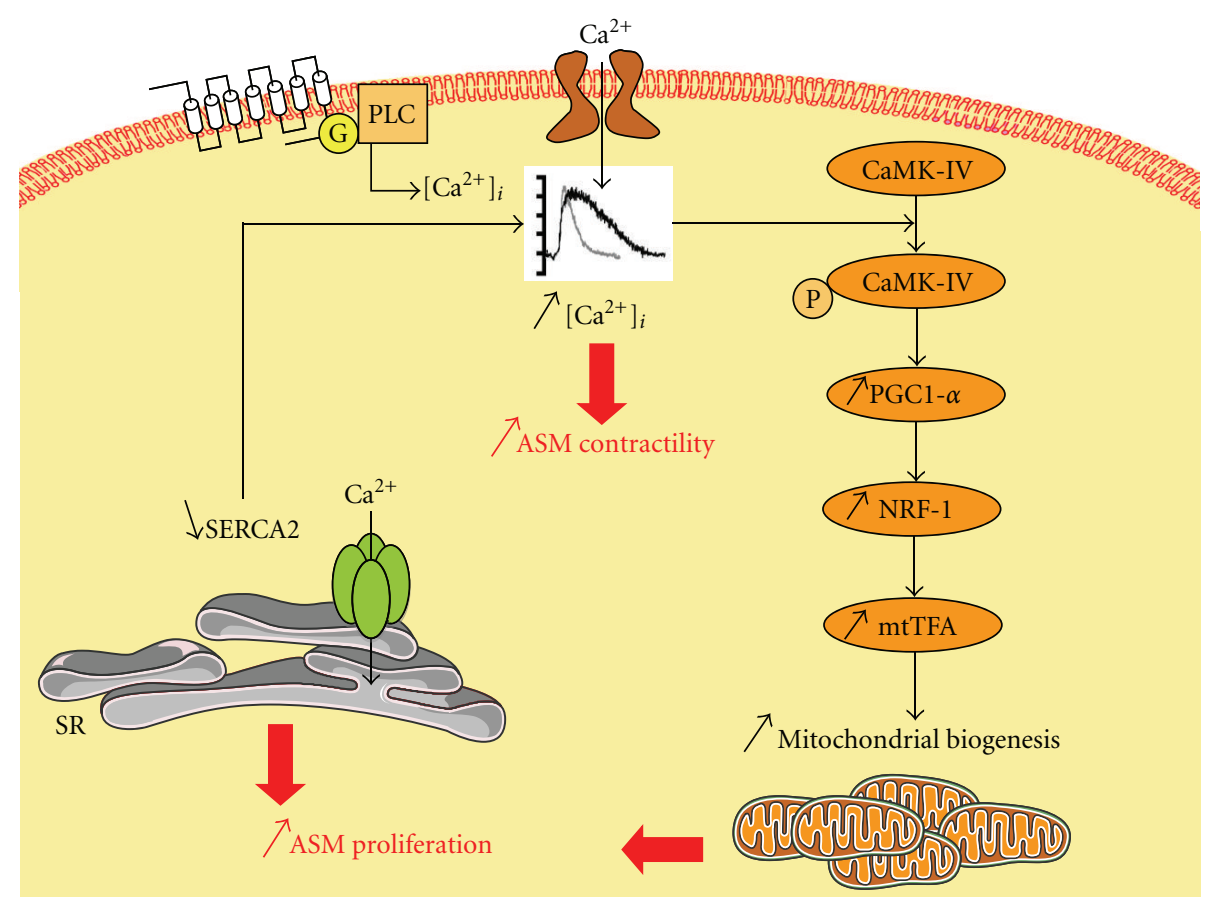

FIGURE 1: Impaired ASM cell calcium homeostasis leading to enhanced proliferation in asthma. In severe asthmatic ASM cells, an altered calcium homeostasis related to an increased influx leads to phosphorylation and activation of CaMK-IV, that, in turns, successively activates PGC-1 $\alpha$, NRF-1, and mtTFA. This transduction pathway results in an increase of mitochondrial biogenesis leading to enhanced ASM proliferation [61]. In nonsevere asthmatic ASM cells, an altered expression and function of SERCA2 may account for the altered calcium homeostasis, which leads to enhanced ASM proliferation [62]. Whatever the mechanism, such altered calcium homeostasis enhances cell contractility. ASM: airway smooth muscle; CaMK-IV: calcium/calmodulin-dependent protein kinase IV; G: G protein; mtTFA: mitochondrial transcription factor A; NRF: nuclear respiratory factor; PGC: peroxisome proliferator-activated receptor $\gamma$ coactivator; PLC: phospholipase C; SERCA: sarcoendoplasmic calcium pomp; SR: sarcoplasmic reticulum.

in vitro AHR to acetylcholine in isolated rabbit ASM tissue and IL-13 reduces responsiveness to adrenaline in human ASM cells [57, 58]. Moreover, mast cell-derived tryptase induces AHR to histamine in vitro using human bronchi from actively sensitized [59] or nonsensitized patients [60] possibly via its enzymatic activity. However, such AHR occurs after an initial calcium response and, thus, in the absence of any spontaneous contraction. Indeed, AHR may also depend on excitation/contraction coupling, which associates two subsequent steps within the ASM cell, that is, (i) the calcium response induced by extracellular messengers and (ii) the calcium sensitivity of the contractile apparatus.

On the one hand, following extracellular stimulation, ASM cytosolic calcium homeostasis is dependant on various components. For instance, the spontaneous return to baseline of the cytosolic calcium concentration is dramatically delayed in asthmatic ASM cells [61]. Such a delay can be related with an abnormal calcium entry [61] and/or with a downregulated expression and function of type 2 of the sarcoendoplasmic calcium pump, that is, SERCA2 [62] (Figure 1). SERCA2 protein expression could be experimentally decreased by IL-13 or TNF- $\alpha$ (TNFSF2) [63]. Alternatively, the proinflammatory cytokine, IL-1 $\beta$, can increase CD38 (ADP-ribosyl cyclase) expression. Then, CD38 increases cyclic ADP-ribose (cADPR) production, which, in turns, activates ryanodin receptor (RyR), leading to an increase in cytosolic calcium concentration [64-66].
In addition, calcium compartmentalization could be another determinant of airway responsiveness. In asthmatic ASM, there could be a greater proportion of intracellular calcium within the deep cytosolic space as compared to the superficial subplasmalemmal space [67], leading to AHR. However, such hypothesis needs to be confirmed.

On the other hand, the calcium sensitivity of the contractile apparatus can be increased, leading to a higher contractile response after a similar ASM intracellular calcium rise [68]. Two different mechanisms have been described according to the dependency or the independency from the myosin light chain kinase/myosin light chain phosphatase (MLCK/MLCP) ratio (Table 3). Regarding MLCK/MLCPdependent AHR, the level of MLCK is increased in asthmatic ASM $[69,70]$. The transcription factor CCAAT/enhancer binding protein- $\alpha(\mathrm{C} / \mathrm{EBP}-\alpha)$ expression is decreased within the asthmatic ASM [71]. Since the promoter that regulates the expression of MLCK contains several C/EBP- $\alpha$ binding sites, such a deficit in C/EBP- $\alpha$ has been proposed to account for the increased expression of MLCK [72]. Nevertheless, such increased expression of MLCK in asthmatic ASM needs to be confirmed since controversial findings have also been reported [73, 74]. Regarding MLCK/MLCP-independent AHR, calcium-independent PKC $\varepsilon$ inhibits calponin, an actin thin filament-associated protein [75] that decreases calcium sensitivity [76]. It also activates mitogen-activated protein kinase (MAPK), which inhibits caldesmon, another actin 
TABLE 3: Excitation/contraction coupling in ASM cells.

\begin{tabular}{|c|c|c|c|c|c|}
\hline MLCK/MLCP balance & Extracellular factors & Intracellular factors & Actions & Consequences & References \\
\hline \multirow{9}{*}{ Dependent } & & CaMKII & I: MLCK & $\mathrm{R}$ & {$[84]$} \\
\hline & $\beta$-adrenergic agonist & PKA & I: MLCK & $\mathrm{R}$ & {$[85]$} \\
\hline & $\beta$-adrenergic agonist & PDE4D increase & I: PKA & $\mathrm{C}$ & {$[86]$} \\
\hline & & PKG & A: MLCP & $\mathrm{R}$ & {$[87]$} \\
\hline & TNF- $\alpha$ (TNFSF2), IL-13 & Rho-kinase & I: MLCP & $\mathrm{C}$ & {$[87]$} \\
\hline & TNF- $\alpha$ (TNFSF2) & Arachidonic acid & A: Rho kinase & $\mathrm{C}$ & {$[88,89]$} \\
\hline & TNF- $\alpha$ (TNFSF 2$)$ & Arachidonic acid & I: MLCP & $\mathrm{C}$ & {$[88,90]$} \\
\hline & & CPI-17 & I: MLCP & $\mathrm{C}$ & {$[87]$} \\
\hline & & C/EBP- $\alpha$ decrease & I: MLCK & $\mathrm{C}$ & {$[72]$} \\
\hline \multirow{8}{*}{ Independent } & & Caldesmon & I: Myosin ATPase activity & $\mathrm{R}$ & {$[91]$} \\
\hline & & Calponin & I: Myosin ATPase activity & $\mathrm{R}$ & {$[92]$} \\
\hline & & $\mathrm{PKC} \varepsilon$ & I: Caldesmon & $\mathrm{C}$ & {$[75]$} \\
\hline & & $\mathrm{PKC} \varepsilon$ & I: Calponin & $\mathrm{C}$ & {$[75]$} \\
\hline & Derp1, LPS & MAPK & I: Caldesmon & $\mathrm{C}$ & {$[75,93,94]$} \\
\hline & TNF- $\alpha$ (TNFSF2), IL-13 & Rho-kinase & I: Calponin & $\mathrm{C}$ & {$[95]$} \\
\hline & & CaMKII & I: Calponin & $\mathrm{C}$ & {$[95]$} \\
\hline & & HSP phosphorylated & I: Contraction & $\mathrm{R}$ & {$[96,97]$} \\
\hline
\end{tabular}

A: active; C: contracting; CaMKII: calcium/calmodulin-dependent protein kinase; CPI-17: 17-kDa PKC-potentiated inhibitory protein of PP1; C/EBP $\alpha$ : CCAAT/enhancer binding protein $\alpha$; Derp1: house dust mite allergen; HSP: heat shock protein; I: inhibit; IL-13: interleukin-13; LPS: lipopolysaccharide; MAPK: mitogen-activated protein kinase; MLCK: myosin light chain kinase; MLCP: myosin light chain phosphatase; PDE4D: phosphodiesterase 4D, cAMPspecific; PKA: cAMP-dependent protein kinase A; PKC $\varepsilon$ : protein kinase C $\varepsilon$; PKG: cGMP-dependent protein kinase G; R: relaxing; PP1: protein phosphatase 1; TNF- $\alpha$ : tumor necrosis factor $\alpha$.

thin filament-associated protein [75] that also decreases calcium sensitivity [76]. Alternatively, RhoA/Rho-kinase signalling, which is increased in experimental asthma, inactivates MLCP leading to MLCK/MLCP-dependent AHR [77], and also inhibits calponin leading to MLCK/MLCPindependent AHR. Such RhoA signalling can be reproduced experimentally, using either the proinflammatory cytokine TNF- $\alpha$ (TNFSF2), which activates RhoA [78], or IL-13, which increases its expression in murine ASM [79].

Finally, the alteration in the dynamic properties of ASM in asthma is still a matter of current debate. The maximal velocity of shortening in ASM from sensitized animals is significantly greater than those in nonsensitized [80] and may be a consequence of an increase in the activity of MLCK [81] but is still controversial (see above). With respect to force generation, although isometric force generated in vitro is directly related to ASM mass in human bronchial ring preparations [82], force generation from asthmatic ASM was not found consistently increased [83].

2.4. Alteration in Contraction/Load Coupling. Like any muscle, ASM may overcome loads that normally moderate ASM shortening [98]. Two main categories of mechanical loads thus apply to ASM: a preload, which is directly related to lung elastic recoil and lung volume, and an afterload, which is determined by the shear modulus of the parenchyma and the coupling of the lung to the airways [98]. Some of these loads reside at the airway cellular/tissular level. Any alteration in such loads against which the ASM contracts and/or in the application of these loads to ASM will result in an alteration in shortening and, hence, airway narrowing.
In asthma, several mechanisms may account for an alteration in the contraction/load coupling [83, 98] such as an increase in lung elastic recoil pressure and a lung expansion that increase the external load that opposes ASM shortening. Indeed, loss of lung elastic recoil related to hyperinflation has been demonstrated in acute asthma [99] and chronic persistent asthma even without emphysema [100]. Moreover, a coupling between lung parenchyma and airways occurs through the attachments of elastic fibers to the airway wall [98]. In healthy individuals, periodic deeper inspirations (DIs) dilate the airways because of an excessive relative airway hysteresis as compared to parenchymal one [101]. In contrast, loss of the beneficial effect of DI is sometimes considered as a hallmark of asthma [102, 103]. Why DI induces bronchoconstriction in some asthmatic patients remains a matter of debate. Leading hypotheses put forward include neurohormonal mechanisms such as increase in cholinergic tone [104] or mechanical mechanisms such as calciumdependent myogenic response of ASM [105] or loss of interdependence between lung parenchyma and airways [106]. Such uncoupling of the forces of interdependence may also be the result of airway inflammation and remodelling, especially thickening and/or oedema of the adventitia [107-109]. Moreover, stiffness of the airway wall may reduce the ability of tidal breathing and DI to stretch ASM, leading to latch bridges between actin/myosin and to a vicious positive feedback $[110,111]$. Finally, altered organization and degradation of ECM proteins might also be less effective to moderate ASM shortening $[83,112,113]$.

On the other hand, thickening of the airway wall and the enhanced amount of ECM also increase airway stiffness and 
TABLE 4: Mediators secreted and immunomodulatory proteins expressed by human ASM cells.

\begin{tabular}{lc}
\hline Factors & References \\
\hline Cell adhesion/costimulatory molecules, receptors & \\
CD11a & {$[117]$} \\
CD40 (TNFRSF5), CD40L (TNFSF5), CD44 & {$[118]$} \\
CD80, CD86 & {$[117]$} \\
OX40L (TNFSF4) & {$[119]$} \\
Adhesion molecules: ICAM-1, VCAM-1 & {$[118]$} \\
Major histocompatibility complex (MHC) II & {$[120]$} \\
Toll-like receptors: TLR2, 3, 4 & {$[121]$} \\
Chemokine receptors: CCR3, 7 & {$[122]$} \\
Chemokine receptors: CXCR1, 3, 4 & {$[122]$} \\
Receptors for IL-4, 6, 12, 13, 17, 22 and IFN- $\gamma$ & {$[116,123]$} \\
Chemokines, cytokines, and growth factors & \\
CCL2, 5, 7, 8, 11, 17, 19 & {$[124-128]$} \\
CXCL8, 10 & {$[129,130]$} \\
CX CL1 & {$[55]$} \\
IL-2, 5, 6, 11, 12 & {$[57,131]$} \\
Interferon- (IFN-) $\gamma$ & {$[57]$} \\
Connective tissue growth factor (CTGF) & {$[132]$} \\
Granulocyte macrophage-colony stimulating factor (GM-CSF) & {$[133]$} \\
Stem cell factor (SCF) & {$[134]$} \\
Transforming growth factor- (TGF-) $\beta 1$ & {$[135]$} \\
Vascular endothelial growth factor (VEGF) & {$[136]$} \\
ECM proteins & \\
Chondroitin sulfate & {$[137]$} \\
Collagens I, III, IV, V & {$[137]$} \\
Decorin, elastin, fibronectin, laminin, perlecan & {$[137]$} \\
Thrombospondin & {$[137]$} \\
Tissue inhibitor of MMPs- (TIMPs-) 1,2 & {$[138]$} \\
Enzymes & {$[139]$} \\
Matrix-metalloproteinases- (MMPs-) 9, 12 & \\
\hline
\end{tabular}

decrease airway compliance [114] that might enable the airways to resist to dynamic compression. Moreover, deposition of connective tissue also acts as mechanical impedance to contraction [113]. Nevertheless, these theoretical advantages of airway remodelling are largely overwhelmed by their negative effects [83].

\section{Role of ASM in Bronchial Inflammation}

While early studies regarding ASM function in asthma focussed on its contractile properties, a growing body of evidence now consistently demonstrates that ASM is no longer a sole target of the inflammatory process. Indeed, ASM cell also displays proinflammatory and immunomodulatory functions $[115,116]$, through its synthetic function and its expression of a wide range of cell surface molecules, integrins, costimulatory molecules, and Toll-like receptors (Table 4). As a consequence, ASM can play an active role, through an autocrine and/or a paracrine manner, in the asthmatic inflammatory process. The molecular and cellular mechanisms modulating ASM cell/inflammatory cell function will be reviewed below, with special attention to those implicating mast cells and T lymphocytes, which are known to infiltrate the asthmatic ASM layer [6].

3.1. ASM/Mast Cell Interaction. There is evidence that the asthmatic ASM layer is infiltrated by an increased number of mast cells [6, 55, 130, 140-147]. Some mast cells are already present in nonasthmatic ASM including smokers [148-152]. However, this mast-cell microlocalization within the asthmatic ASM, termed mast cell myositis [153], appears to be a specific feature of asthma, being absent in patients suffering from eosinophilic bronchitis and healthy subjects $[140,145]$. Interestingly, the mast cell myositis is observed in various asthma phenotypes, including eosinophilic and noneosinophilic asthma [154], and also atopic and non atopic asthma, even if the number of mast cells is significantly higher in the ASM of atopic asthmatics [142]. Moreover, mast cell myositis is unchanged whether asthma is treated or not $[145,146]$, or regardless of asthma severity $[143,145-$ 147]. 


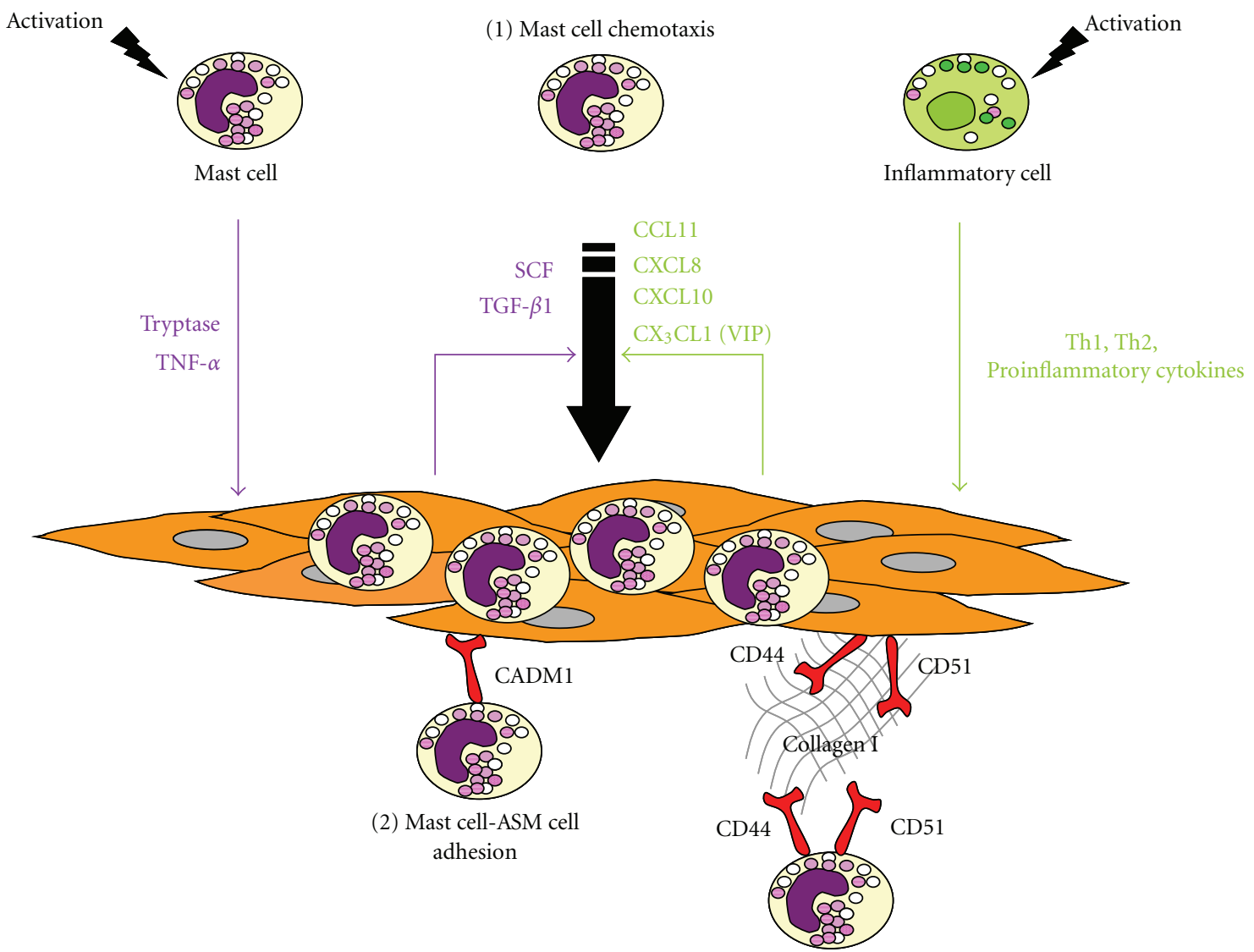

(3) Mast cell-ECM-ASM cell adhesion

FIGURE 2: Mechanisms underlying mast cell myositis in asthma. In asthma, the mechanisms leading to an infiltration of airway smooth muscle (ASM) layer by mast cells, termed mast cell myositis, involve (1) mast cell chemotaxis towards the ASM bundle, (2) direct mast cell-ASM cell adhesion, and (3) mast cell-extracellular matrix- (ECM-) ASM cell adherence. Upon mast cell activation, mast cells release mediators which activate ASM cells, such as tryptase and TNF- $\alpha$ (TNFSF2). As a consequence, ASM cells produce and secrete chemotactic factors for mast cells, leading to an autoactivation loop. Under stimulation by Th1, Th2, and/or proinflammatory cytokines, produced by various inflammatory cells, ASM cells also secrete a wide range of mast cell chemotactic factors.

The mechanism of such a myositis has been firstly related to the production of mast cell chemotactic factors by the ASM itself, through an autoactivation loop [144] (Figure 2). Indeed, upon activation, mast cells release tryptase and proinflammatory cytokines, such as TNF- $\alpha$ (TNFSF2), which stimulate the production of TGF- $\beta_{1}$ and, to a lesser extent, SCF by ASM cells, which in turns, induce mast cell chemotaxis [144]. Moreover, ASM can promote mast cell chemotaxis through the secretion of a wide array of chemoattractants, upon stimulation by Th1 [130], Th2 [130, 155] or proinflammatory cytokines $[55,144]$. For instance, ASM also produces functionally active CXCL10 [130], CXCL8 [155], CCL11 [155], and $\mathrm{CX}_{3} \mathrm{CL1}$ [55], even if, for CX $\mathrm{CX}_{3}$ CL1, the additional presence of VIP is necessary [55]. Taken together, these findings support the view that mast cell migration depends on various mediators secreted by ASM and is closely related to ASM inflammatory microenvironment.

Once present within the ASM bundle, mast cells can adhere to ASM. This adhesion has been initially ascribed to a cell-cell interaction involving an Ig superfamily member, that is, cell adhesion molecule 1 (CADM1), previously known as tumor suppressor in lung cancer 1 (TLSC-1 ) $[156,157]$ (Figure 2). However, blocking CADM1 leads to only a partial reduction in the adhesion of mast cells to ASM, suggesting additional mechanisms are present [156]. Indeed, mast cell-ASM adherence also involves cell-ECM-cell interaction through type I collagen, CD44, and CD51 [2] (Figure 2). This adhesion is improved under inflammatory conditions or using asthmatic ASM cells [2]. These in vitro findings are in agreement with ultrastructural analysis of asthmatic ASM using electron microscopy, demonstrating the absence of direct cell-cell contact between ASM and mast cells [6].

The majority of mast cells infiltrating the asthmatic ASM layer are typically of the $\mathrm{MC}_{\mathrm{TC}}$ phenotype, containing both tryptase and chymase $[140,158,159]$. Interestingly, these mast cells infiltrate ASM in both large and small airways, and exhibit marked features of chronic ongoing activation [142, 143]. Such findings were also confirmed by ultrastructural analysis of ASM using electron microscopy [6]. However, little is known about the mechanisms by which mast cell activation may occur within the ASM layer [160]. Mast cell degranulation may result from IgE-dependent 
activation, especially in atopic patients [142]. However, IgEindependent mechanisms have also been evoked, following mast cell-ASM interaction through the complement C3a or SCF $[42,157,161,162]$, for instance, or following bacterial or viral infection through Toll-like receptors [160].

Taking into account the following characteristics: (i) microlocalization of mast cells within the ASM layer, (ii) mast cell adherence to the ASM, and (iii) mast cell activation within the ASM, it is tempting to consider that a close functional relationship may exist between these two cell types.

On the one hand, mast cells alter functional and phenotypic properties of ASM cells. Indeed, mast cell-derived mediators contribute to AHR and ASM remodelling [12]. For instance, the major mast cell product, tryptase, induces both ASM calcium response [30] and AHR to histamine in vitro [60] or in vivo [163]. Tryptase also increases ASM cell-TGF- $\beta 1$ secretion, which, in turns, promotes ASM cells differentiation towards a contractile phenotype, characterized by an increase expression of $\alpha$-actin and enhanced contractility [42]. Interestingly, the number of mast cells within the ASM layer is positively correlated with the degree of AHR $[140,145]$, and with the intensity of $\alpha$-smooth muscle actin [42].

Mast cell myositis may also promote ASM remodelling. However, although several mast cell products such as tryptase are known to individually stimulate both DNA synthesis and ASM proliferation [164], coculturing ASM and mast cells does not increase proliferation [161]. Similarly, ASM survival is not enhanced by mast cell interaction [161]. Both mast and ASM cell-derived CCL19 mediate ASM migration through ASM CCR7 activation [128]. By contrast, CCL11/CCR3-mediated ASM cell migration was inhibited by mast cells [165]. No correlation was found between the number of mast cells in the ASM and ASM mass, supporting the modest role of mast cells in ASM remodelling [142].

On the other hand, ASM cells alter functional and phenotypic properties of mast cells. Indeed, ASM cells can promote mast cell survival, hence providing a favorable microenvironnement for mast cells [157]. They also enhance their proliferation, through a mechanism involving a cooperative interaction between ASM membrane-bound SCF, soluble IL-6, and mast cell-expressed CADM1 [157]. ASM cells-derived ECM proteins may also promote mast cells differentiation towards a fibroblastoid phenotype, characterized by the expression of fibroblast markers and fibroblastlike morphology. This feature seems to be specific of mast cells within the ASM layer, since fibroblast markers are not expressed in submucosal mast cells [147].

3.2. ASM/T Cell Interaction. Up to now, only few studies have documented $\mathrm{T}$ cell infiltration within the ASM layer in asthma. $\mathrm{CD}^{+} \mathrm{T}$ cell microlocalization within ASM layer was first reported in an elegant experimental rat asthma model [166]. This finding was further confirmed in human asthmatics $[6,15]$ and is related to asthma severity [15]. Moreover, this feature appears to be specific of asthma, since $\mathrm{T}$ cells were not found in the ASM layer of control subjects, but within and beneath the epithelium [15]. As compared to mast cell ASM infiltration, there is a relative paucity of T cells within the ASM layer $[6,140]$. However, ASM cells are able to produce appropriate chemotactic factors for $\mathrm{T}$ cells, such as CCL5 [125]. In this respect, a possible role for mast cell chymase has been suggested since this protease is known to inhibit $\mathrm{T}$ cell adhesion to nonasthmatic ASM cells in vitro [167]. Nonetheless, close contact were pointed out between ASM cells and T cells in asthma ex vivo $[6,15]$, hence suggesting cell-cell adherence between these two cell types.

Lazaar and coworkers originally demonstrated that activated $\mathrm{T}$ cells can adhere in vitro to resting ASM cells from nonasthmatic patients and that such an adhesion was enhanced when ASM cells were primed with proinflammatory cytokines such as TNF- $\alpha$ (TNFSF2) [118]. These findings were independently further confirmed [117]. This adhesion involves CD44, intercellular cell adhesion molecule 1 (ICAM-1), vascular cell adhesion molecule 1 (VCAM-1) expressed by ASM cells, and CD44, lymphocyte functionassociated antigen 1 (LFA-1) and very late antigen 4 (VLA-4) expressed by T cells [118]. More recently, nonasthmatic ASM cells, pulsed to the superantigen staphylococcal enterotoxin A (SEA), have been shown to adhere to $\mathrm{T}$ cells by presenting the SEA via their MHC class II [168]. Although ASM cells express MHC class II, constitutively as well as under stimulation $[117,120]$, they are not classically considered as an antigen-presenting cell. Consequently, these findings support an emerging role of ASM cell as an immunomodulatory cell. However, except for VCAM-1, which forms clusters in the asthmatic ASM ex vivo suggesting VCAM1 mediated intercellular signalling, the role of the above molecules in adherence between T cell and ASM cell from asthmatic patients has not yet been considered. Two other ASM cell-surface molecules, CD40 (TNFRSF5) [117, 169171] and OX40 ligand (TNFSF4) [119, 171, 172], both expressed in asthmatic and nonasthmatic ASM cells, may also play a role in promoting ASM cell-T cell adherence. These costimulatory cell-surface molecules, members of the TNF superfamily, respectively, bind to CD40L (TNFSF5) and OX40 (TNFRSF4) on activated T cells [173, 174]. However, their role in the adherence of $\mathrm{T}$ cells to asthmatic ASM remains to be investigated.

Close interaction between T cells and ASM cells may lead to stimulatory cross-talk between these two cell types, but little is known about the functional consequences of such an interaction. On the one hand, $\mathrm{T}$ cells may alter functional properties of ASM cells. In this connection, $\mathrm{T}$ cells alter ASM contractile phenotype, enhancing ASM contractility to acetylcholine and reducing its relaxation to isoproterenol in isolated rabbit ASM tissue [117]. T cells may also drive ASM remodelling, in particular ASM hyperplasia $[15,118,166]$. Indeed, in an experimental rat asthma model, adoptively transferred $\mathrm{CD}^{+} \mathrm{T}$ cells from OVA-sensitized rats increases ASM mass, which is both associated with an increased ASM proliferation and decreased apoptosis ex vivo [166]. Such an increased ASM proliferation and decreased apoptosis was confirmed in vitro only upon direct $\mathrm{CD}^{+}{ }^{+} \mathrm{T}$ cells-ASM cells contact, highlighting the need for close cellular interaction between these two cell types [166]. These observations are in agreement with a previous study 


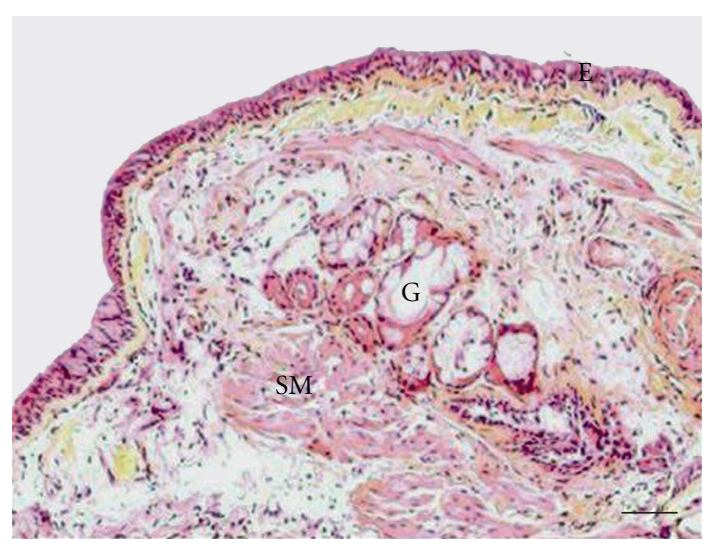

(a)

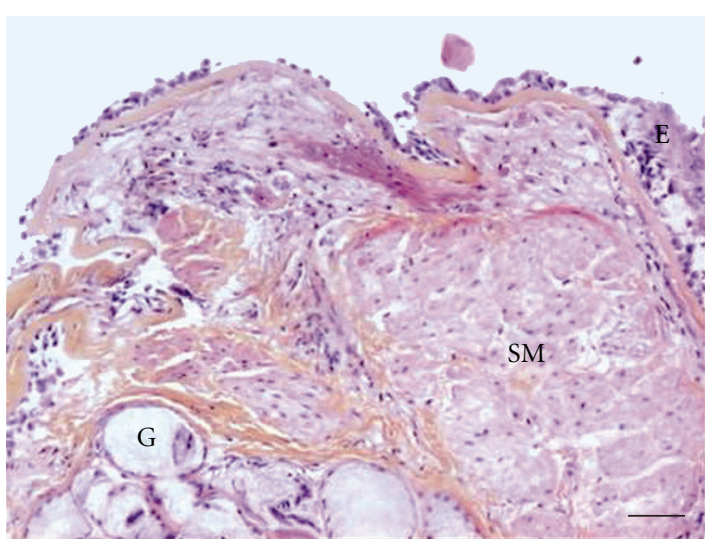

(b)

FIGURE 3: Representative optic microscopic from bronchial sections stained with Haematoxylin, Eosin, and safranin stain were obtained from (a) a control subject or (b) an asthmatic patient (printed from Bara et al. [12], with permission of European Respiratory Journal publisher) E: epithelium; G: mucous gland; SM: smooth muscle. Scale bars represent $50 \mu \mathrm{m}$.

demonstrating in vitro a role for T cell in ASM DNA synthesis and proliferation in ASM cells from nonasthmatic patients [118]. The role of $\mathrm{T}$ cells in driving ASM remodelling was later confirmed in human asthmatics [15]. Moreover, the number of T cells infiltrating the asthmatic ASM correlates with ASM mass [15]. Collectively, these findings suggest an emerging role of T cells in both ASM hyperresponsiveness and remodelling.

On the other hand, ASM cells may also alter functional properties of $\mathrm{T}$ cells. Indeed, a direct contact between $\mathrm{CD}^{+} \mathrm{T}$ cells and ASM cells also enhances $\mathrm{T}$ cell survival, thus possibly contributing to the perpetuation of bronchial inflammation [166]. Moreover, cultured human nonasthmatic ASM cells are able to present superantigens via their MHC class II molecules to resting $\mathrm{CD}^{+} \mathrm{T}$ cells [168], which leads to $\mathrm{CD} 4^{+} \mathrm{T}$ cells activation, adherence between these cells, and finally release of IL-13, that, in turns, leads to increase in the contractile response to acetylcholine of isolated rabbit ASM tissues [168].

\section{Role of ASM in Bronchial Remodelling}

ASM remodelling represents a key feature of asthmatic bronchial remodelling [12] (Figure 3). Indeed, many lines of evidence demonstrate an increase in ASM mass in fatal [175] and nonfatal asthma [15, 61, 70, 142]. However, ASM remodelling is still insensitive to current asthma medications [176] that are usually effective in treating acute airway narrowing and bronchial inflammation. Furthermore, ASM cell plays also a role in promoting other bronchial remodelling structural alterations, in particular by virtue of its synthetic function. For instance, ASM cells can release biologically active TGF- $\beta$ [177], which is involved in various structural alterations such as epithelial changes, subepithelial fibrosis, mucus hypersecretion, goblet cell hyperplasia, and angiogenesis [178].

The mechanisms underlying ASM remodelling involve ASM hyperplasia, ASM hypertrophy, and an excessive deposition of proteins of the ECM [12].
4.1. ASM Hyperplasia. Three mechanisms may account for ASM hyperplasia, that is, (i) ASM cell proliferation, (ii) reduced ASM cell apoptosis, and more recently (iii) migration of myofibroblasts within the ASM layer.

4.1.1. ASM Cell Proliferation. Compelling evidence now suggests an excessive ASM cell proliferation in asthma both in vitro $[61,62,71,179,180]$ and in vivo $[15,181]$. However, before these two recent studies $[15,181]$, the number of proliferative ASM cells in vivo was a matter of debate since the number of PCNA or Ki67 positive ASM cells was unchanged in asthmatic bronchial samples $[6,70]$. The reason for this discrepancy is apparently related with the fixation process.

A wide array of mitogenic factors are known to promote ASM cell proliferation in vitro, including growth factors, cytokines, chemokines, inflammatory mediators, enzymes, ECM components, reactive oxygen species, and mechanical stress (Table 5). Such mitogenic factors promote ASM cell proliferation by activating pathways involving either receptor tyrosine kinase (RTK) or receptor coupled to heterotrimeric $G$ proteins (GPCR) [182]. Upon activation of these receptors, downstream transduction pathways usually involve Ras, phosphatidylinositol 3-kinase (PI3K) or MAPK/ERK kinase (MEK) and extracellular signal-regulated kinase (ERK), which in turns induce cyclin D1 expression [182].

However, asthmatic ASM cells can also proliferate faster in vitro than nonasthmatic ASM cells irrespective of extracellular stimuli [179], hence supporting the view that an intrinsic ASM abnormality does exist in asthma. In this respect, ASM tissue-specific decreased levels of $\mathrm{C} / \mathrm{EBP} \alpha$ were found in asthmatics and could explain enhanced proliferation [71], through downregulation of the cell-cycle inhibitor p21. In addition, steroids are less effective in asthmatic ASM cells, since $\mathrm{C} / \mathrm{EBP} \alpha$ expression is impaired [71]. An alternative, or complementary, ASM tissue-specific explanation for the increased asthmatic ASM cell proliferation is an alteration of ASM calcium homeostasis. In severe asthma, an abnormal extracellular calcium entry leads to subsequent activation of peroxisome proliferator-activated receptor $\gamma$ 
TABle 5: Mitogenic factors for human ASM cells.

\begin{tabular}{lc}
\hline Classification & References \\
\hline Growth factors/cytokines/chemokines & \\
Platelet-derived growth factor (PDGF) & {$[211]$} \\
Fibroblast growth factor (FGF) & {$[212]$} \\
Epidermal growth factor (EGF) & {$[213]$} \\
Tumor necrosis factor- (TNF-) $\alpha$ (TNFSF2) & {$[214]$} \\
Transforming growth factor- (TGF-) $\beta 1$ & {$[215,216]$} \\
(controversial) & {$[186]$} \\
CCL3, 5, 11 & {$[186]$} \\
CXCL8 & \\
Inflammatory mediators & {$[217]$} \\
Histamine & {$[218]$} \\
Endothelin-1 & {$[219]$} \\
Thromboxane A2 & {$[220]$} \\
Sphingosine 1-phosphate & {$[221]$} \\
Cysteinyl leukotrienes (LTC4, LTD4, LTE4) & \\
Enzymes & {$[164]$} \\
Tryptase & {$[222]$} \\
Thrombin & {$[223]$} \\
Elastase & {$[224]$} \\
Matrix metalloproteinases & {$[226]$} \\
ECM components & {$[225]$} \\
Fibronectin & \\
Collagen I & \\
Others & {$[22]$} \\
Reactive oxygen species & \\
Mechanical stress & \\
Brain derived neurotrophic factor (BDNF) & \\
\hline & \\
&
\end{tabular}

coactivator- $1 \alpha$ (PGC- $1 \alpha)$, nuclear respiratory factor-1 (NRF1), and mitochondrial transcription factor A (mtTFA) [61]. This transduction pathway results in an increased mitochondrial biogenesis leading to enhanced ASM proliferation [61] (Figure 1). Interestingly, such enhanced mitochondrial biogenesis was not observed in other cell types, such as endothelial or epithelial cells, highlighting the smooth muscle specificity of such findings [61]. More recently, ASM calcium homeostasis has also been shown to be impaired in nonsevere asthma, via a different mechanism [62]. Such mechanism implicates reduced SERCA2 expression in both native and cultured ASM cells, but origin of such defect in asthmatic ASM remains unknown [183] (Figure 1).

4.1.2. Reduced ASM Apoptosis. Another explanation is to consider that ASM hyperplasia may be due to an imbalance between ASM proliferation and death. However, little is known about processes that may counterbalance ASM proliferation, such as apoptosis. Indeed, by contrast to the substantial evidence supporting ASM proliferation, only few studies have investigated ASM cells survival signals, ASM cell spontaneous apoptosis, or their susceptibility to apoptosis in response to proapoptotic factors. Most of the current knowledge about apoptotic pathways in ASM originates from nonasthmatic ASM cells.
Cardiotrophin-1 [184], endothelin-1 [185], chemokines, such as CCL3, CCL5, CCL11, and CXCL8 [186], or some ECM components, including fibronectin, laminin, and collagens I and IV [187], inhibit nonasthmatic ASM cell apoptosis. ASM cells express in vitro the death receptors TNFR1 (TNFRSF1A), Fas (TNFRSF6), TRAILR1 (TNFRSF10A), TRAILR2 (TNFRSF10B) [188], and stimulation of ASM cells either with TNF- $\alpha$ (TNFSF2) $[188,189]$, soluble Fas ligand (TNFSF6) [188], Fas antibody [189], or TRAIL (TNFSF10) [188] induces cell apoptosis. Similarly, hydrogen peroxideexposure decreases ASM cells survival and is prevented by overexpression of the small heat shock protein 27 (Hsp27), in part by upregulating glutathione levels [190]. ECM-degrading proteinase, such as neutrophil elastase, may also induce ASM cell apoptosis by triggering detachment from the ECM [191], which results in the withdrawal of survival signals usually provided by some ECM components [187]. Conversely, some ECM components, such as decorin, may also induce ASM cells apoptosis in vitro [192]. Some treatments are also able to induce nonasthmatic ASM cell apoptosis in vitro. Indeed, activation of peroxisome proliferator-activated receptor $\gamma(\operatorname{PPAR} \gamma)$, which is expressed by ASM cells, by its synthetic ligand commonly used in diabetes treatment, may also induce apoptosis [193]. Moreover, simvastatin, an HMG-CoA reductase inhibitor, has recently been shown to trigger ASM cells apoptosis through the intrinsic apoptotic pathway involving p53, enhanced mitochondrial permeability, mitochondrial release of Smac and Omi, and inhibition of mitochondrial fission, which in turns leads to the activation of caspases 9, 7 and 3 [194]. However, the role of these different mediators and signalling pathways in asthmatic ASM cell survival remains unknown.

In asthma, the hypothesis of an imbalance between ASM proliferation and apoptosis is mainly supported by a rat model of T-cell driven remodelling [166]. Furthermore, an increased expression of TRAIL (TNFSF10) has also been shown ex vivo in asthmatic ASM following allergen challenge, suggesting that this cytokine may play a role in asthmatic ASM apoptosis [195]. Besides, active caspase 3 expression and double stranded DNA breaking were shown ex vivo in ASM, in severe asthma, and in case of fatal asthma, respectively [188]. Conversely, such findings were not reported in intermittent asthma [188] and Benayoun and coworkers failed to demonstrate active caspase 3 expression ex vivo, irrespective of asthma severity [196]. In vitro, two reports have also drawn negative results, showing no change in spontaneous apoptosis within asthmatic ASM cells [61, 161]. As a consequence, further studies remain to be undertaken to determine whether or not there is a change in asthmatic ASM cell apoptosis.

4.1.3. Migration of ASM Cells and Myofibroblasts. More recently, it has been suggested that migration of ASM precursor cells, either located within the bronchial wall or derived from peripheral blood fibroblast progenitors, towards the ASM bundles may also participate in ASM hyperplasia [197]. Cellular migration is characterized by significant cytoskeletal remodelling with apparition of filopodia and lamellipodia to 
increase directed movement along a concentration gradient (chemotaxis) and/or nondirected movement (chemokinesis) [197].

Migration of myofibroblasts may participate in ASM hyperplasia, by differentiating to ASM-like cells [197]. Such an hypothesis was based on the microlocalization of myofibroblasts between ASM bundles [6], while an increased number of myofibroblasts has been demonstrated within the lamina reticularis, especially after allergen challenge [198], and within the lamina propria [15].

However, the origin of myofibroblasts remains a source of debate and several hypotheses have been put forward. First, myofibroblasts may come from resident fibroblasts that have differentiated [199] or from dedifferenciation of ASM cells themselves, which have migrated out of the ASM bundles towards the lumen [199]. Indeed, a wide range of mediators may promote in vitro human nonasthmatic ASM cell migration, such as cytokines, growth factors, chemokines, and some ECM components [197] (Table 6). The major transduction pathways so far identified for ASM cell migration involve PI3K, Rho-kinase, MAPK, p38, and phosphorylation of Hsp27 [197, 200]. Migration is also a strongly calciumdependent process $[62,128]$. Thus, enhanced cell spreading, which might reflect migration, was observed in asthmatic ASM cells lacking SERCA2, while knocking down SERCA2 using small interfering RNA in nonasthmatic ASM cells leads to earlier lamellipodia and enhanced cell spreading [62]. Whereas this first study suggests that asthmatic ASM cells might migrate more than nonasthmatic ASM cells [62], such findings require further investigations, as well as addressing directly ASM cell migration in vivo.

Myofibroblasts can also originate from epithelial cells undergoing phenotypic changes through epithelial-mesenchymal transition process [201-203]. Another hypothesis is that myofibroblasts come from the recruitment of circulating bone-marrow-derived progenitors, termed fibrocytes [204208]. Fibrocytes may be identified by the coexpression of the stem cell marker CD34 and/or the panhematopoietic marker CD45 and collagen-1 [209]. In this setting, a growing body of evidence supports the concept of fibrocytes trafficking to the lung in asthma, both in mouse asthma models [204, 208] and in humans [204-207]. Indeed, fibrocyte localization has been found within the bronchial wall in asthma [204], in particular, within the ASM bundles irrespective of asthma severity [206], close to the basement membrane [207], in the lamina propria [206], or below the epithelium [204, 208]. Fibrocytes differentiate into myofibroblasts, as evidenced by the concomitant expression of fibrocyte markers and $\alpha$-smooth muscle actin [204, 205]. Mechanisms underlying such fibrocyte chemotaxis to the lung are in part mediated by ASM secreted-PDGF [206], which also promotes fibrocyte differentiation to myofibroblast [205]. Besides, such chemotaxis might likewise involve the chemokine receptors CXCR4, CCR2, CCR3, CCR4, CCR5, CCR7, and the chemokines CCL3, CCL4, CCL5, CCL7, CCL8, CCL11, and CCL13 [210]. Interestingly, circulating fibrocytes number is positively correlated to the slope of the yearly decline in $\mathrm{FEV}_{1}$ [205],
TABLE 6: Promigratory factors for human ASM cells.

\begin{tabular}{lc}
\hline Factors & References \\
\hline Growth factors/cytokines/chemokines & \\
FGF2, PDGF, TGF- $\alpha$ (TNFSF2), TGF- $\beta$ & {$[229,230]$} \\
IL-1 $\beta$, IL-17A, IL-17F, IL-22 & {$[123,230]$} \\
CCL5, 11, 19 & {$[128,231$,} \\
CXCL8 & $232]$ \\
Leukotriene E4 & {$[231]$} \\
ECM components & {$[233]$} \\
Collagens I, III, V & \\
Fibronectin, laminin & {$[233]$} \\
Enzymes & {$[233]$} \\
Matrix metalloproteinase- (MMP-)3 & \\
Others & {$[234]$} \\
Thrombin & \\
Urokinase plaminogen activator & {$[235]$} \\
\hline
\end{tabular}

once again suggesting a role of fibrocytes in ASM remodelling.

4.2. ASM Hypertrophy. Unlike ASM cell hyperplasia, evidence for ASM cell hypertrophy in asthma remains a matter of debate $[6,70,74,175]$. In fact, increased ASM cell size has been reported in tissue specimens from intermittent [70], mild-to-moderate [70], severe [70], fatal [175], and atopic asthma [6]. However, conflicting findings were found in mild-to-moderate asthma [74]. As a consequence, it has been suggested that ASM cell hypertrophy might be a hallmark of severe asthma status, since it can discriminate patients with severe asthma from those with milder disease [70]. Interestingly, ASM cell hypertrophy was associated with an increased amount of MLCK, which is involved in AHR [70]. Nevertheless, whether ASM hypertrophy is a condition sufficient to induce AHR in asthma needs further investigations.

The underlying mechanisms of such ASM cell hypertrophy remain unknown in asthma. Cardiotrophin-1 [184], serum deprivation [237], TGF- $\beta$ [238], and endothelin-1 [185] can drive ASM cell hypertrophy in vitro, and only in nonasthmatic ASM cells. More recently, the role of miRNA26a, whose expression is increased by mechanical stretch, has been highlighted in ASM cell hypertrophy [239]. However, the role of these factors needs to be clarified in asthma, as well as the putative role of SERCA2, whose expression is known to be also reduced in cardiac hypertrophy [240].

Two distinct transduction pathways can lead to ASM cell hypertrophy [241]. Pathways can involve the mammalian target of rapamycin (mTOR), 4E-binding protein (4E-BP), the transcription factor eIF4E [242], and S6 kinase [243] or the inhibition of glycogen synthase kinase- (GSK-) $3 \beta$ [244], for instance, by the serine/threonine kinase Akt [241]. However, involvement of such transduction pathways needs to be further investigated in asthmatic ASM cell hypertrophy.

4.3. Altered ECM within the ASM Layer. Alteration in ECM represents another feature of ASM remodelling [12]. ECM is increased in asthma [6], as a result of increased deposition 
of ECM proteins by airway resident cells, such as epithelial cells, fibroblasts, myofibroblasts, and ASM cells (Table 4). Its composition is different from that of nonasthmatics [139]. Histological examination of asthmatic bronchial samples reveals enhanced deposition of ECM proteins in the bronchial wall, such as collagens I, III, V, fibronectin, tenascin, hyaluronan, versican, laminin, lumican, and biglycan $[245,246]$, while collagen IV and elastin are decreased [247]. However, conflicting findings have also been reported regarding, the amount of collagen III $[248,249]$, collagen IV [250] and elastin [251] in the asthmatic bronchial wall. Interestingly, ECM is also increased all around ASM cells regardless of asthma severity $[6,252]$. Such increase may be due to decreased matrix metalloproteinases (MMPs), which degrade ECM proteins, and/or increased tissue inhibitors of MMPs (TIMPs). Thus, overexpression of TIMP-1 and TIMP2 may account for low MMPs activity in asthma [138]. The profile of ECM proteins produced in vitro by asthmatic ASM cells is also different from that of nonasthmatic ASM cells, with more perlecan and collagen I, and less laminin- $\alpha 1$ and collagen IV [253].

Nevertheless, whether such alterations in ASM ECM products contribute to modulate composition of the overall bronchial ECM remains unknown. Conversely, increasing evidence supports the role of ECM in modulating several aspects of ASM function [254]. In fact, fibronectin and collagen I have been reported to promote ASM proliferation from nonasthmatic donors in a dose-dependant fashion (Table 5), whereas laminin inhibits growth [255]. Fibronectin, collagens I, IV, and laminin also provide strong survival signals for ASM cells and such an effect is mediated at least in part through the fibronectin receptor/ $\alpha 5 \beta 1$ integrin [187]. Moreover, ASM cell contact with membranes coated with ECM components, such as fibronectin, collagens III and V, has been shown to enhance ASM migration [233] (Table 6). Synthetic properties of ASM cells may also be modulated by ECM components, such as IL- $1 \beta$-dependent ASM secretion of CCL5 and CCL11 [256]. More recently, ECM has been involved in triggering ASM maturation to the contractile phenotype upon serum deprivation [257].

\section{Conclusion}

ASM cell plays a pivotal position in the pathophysiology of asthma as (i) a main effector of AHR, (ii) a proinflammatory and immunomodulatory cell through its synthetic properties and its expression of a wide range of cell surface molecules, and (iii) a leading cell involving in bronchial remodelling. If AHR and bronchial inflammation respond fairly well to conventional therapy such as bronchodilators and antiinflammatory drugs, ASM remodelling remains insensitive to these treatments [176]. Targeting the various functions of ASM represents therefore a challenge for future asthma treatments $[5,12,176]$. In particular, research needs to focus on ways to prevent and/or reverse ASM remodelling. In this connection, targeting mitochondrial biogenesis and/or developing proapoptotic strategies to induce ASM cell death may represent an attractive area of investigation. In this respect, development of noninvasive tools for quantifying
ASM remodelling has received increasing attention in order to evaluate on a long-term basis the efficacy of such treat ments [258].

\section{References}

[1] W. W. Busse and R. F. Lemanske Jr., "Asthma," The New England Journal of Medicine, vol. 344, no. 5, pp. 350-362, 2001.

[2] P. O. Girodet, A. Ozier, T. Trian et al., "Mast cell adhesion to bronchial smooth muscle in asthma specifically depends on CD51 and CD44 variant 6," Allergy, vol. 65, no. 8, pp. 1004-1012, 2010.

[3] D. Denis, M. J. Fayon, P. Berger et al., "Prolonged moderate hyperoxia induces hyperresponsiveness and airway inflammation in newborn rats," Pediatric Research, vol. 50, no. 4, pp. 515-519, 2001.

[4] J. L. Black and M. Roth, "Intrinsic asthma: is it intrinsic to the smooth muscle?" Clinical and Experimental Allergy, vol. 39, no. 7, pp. 962-965, 2009.

[5] S. Zuyderduyn, M. B. Sukkar, A. Fust, S. Dhaliwal, and J. K. Burgess, "Treating asthma means treating airway smooth muscle cells," European Respiratory Journal, vol. 32, no. 2, pp. 265-274, 2008.

[6] H. Begueret, P. Berger, J. M. Vernejoux, L. Dubuisson, R. Marthan, and J. M. Tunon-De-Lara, "Inflammation of bronchial smooth muscle in allergic asthma," Thorax, vol. 62, no. 1, pp. 8-15, 2007.

[7] L. A. Laitinen, M. Heino, A. Laitinen et al., "Damage of the airway epithelium and bronchial reactivity in patients with asthma," American Review of Respiratory Disease, vol. 131, no. 4, pp. 599-606, 1985.

[8] J. Bousquet, J. Y. Lacoste, P. Chanez, P. Vic, P. Godard, and F. B. Michel, "Bronchial elastic fibers in normal subjects and asthmatic patients," American Journal of Respiratory and Critical Care Medicine, vol. 153, no. 5, pp. 1648-1654, 1996.

[9] M. S. Dunnill, G. R. Massarella, and J. A. Anderson, "A comparison of the quantitative anatomy of the bronchi in normal subjects, in status asthmaticus, in chronic bronchitis, and in emphysema," Thorax, vol. 24, no. 2, pp. 176-179, 1969.

[10] N. G. Carroll, C. Cooke, and A. L. James, "Bronchial blood vessel dimensions in asthma," American Journal of Respiratory and Critical Care Medicine, vol. 155, no. 2, pp. 689-695, 1997.

[11] N. Carroll, J. Elliot, A. Morton, and A. James, "The structure of large and small airways in nonfatal and fatal asthma," American Review of Respiratory Disease, vol. 147, no. 2, pp. 405-410, 1993.

[12] I. Bara, A. Ozier, J. M. Tunon de Lara, R. Marthan, and P. Berger, "Pathophysiology of bronchial smooth muscle remodelling in asthma," European Respiratory Journal, vol. 36, no. 5, pp. 1174-1184, 2010.

[13] C. Pepe, S. Foley, J. Shannon et al., "Differences in airway remodeling between subjects with severe and moderate asthma," Journal of Allergy and Clinical Immunology, vol. 116, no. 3, pp. 544-549, 2005.

[14] M. Kaminska, S. Foley, K. Maghni et al., "Airway remodeling in subjects with severe asthma with or without chronic persistent airflow obstruction," Journal of Allergy and Clinical Immunology, vol. 124, no. 1, pp. 45.e1-51.e4, 2009.

[15] D. Ramos-Barbon, R. Fraga-Iriso, N. S. Brienza et al., "T cells localize with proliferating smooth muscle $\alpha$-actin ${ }^{+}$cell compartments in asthma," American Journal of Respiratory and Critical Care Medicine, vol. 182, no. 3, pp. 317-324, 2010. 
[16] J. S. Kim and B. K. Rubin, "Nasal and sinus inflammation in chronic obstructive pulmonary disease," Journal of Chronic Obstructive Pulmonary Disease, vol. 4, no. 2, pp. 163-166, 2007.

[17] N. Watson, H. Magnussen, and K. F. Rabe, "Pharmacological characterization of the muscarinic receptor subtype mediating contraction of human peripheral airways," Journal of Pharmacology and Experimental Therapeutics, vol. 274, no. 3, pp. 1293-1297, 1995.

[18] P. M. O’Byrne and M. D. Inman, "Airway hyperresponsiveness," Chest, vol. 123, no. 3, supplement, pp. 411S-416S, 2003.

[19] S. D. Anderson, "Indirect challenge tests: airway hyperresponsiveness in asthma: its measurement and clinical significance," Chest, vol. 138, no. 2, supplement, pp. 25S-30S, 2010.

[20] S. D. Anderson, "How does exercise cause asthma attacks?" Current Opinion in Allergy and Clinical Immunology, vol. 6, no. 1, pp. 37-42, 2006.

[21] R. E. Altounyan, "Variation of drug action on airway obstruction in man," Thorax, vol. 19, pp. 406-415, 1964.

[22] E. Adelroth, M. M. Morris, F. E. Hargreave, and P. M. O’Byrne, "Airway responsiveness to leukotrienes C4 and D4 and to methacholine in patients with asthma and normal controls," The New England Journal of Medicine, vol. 315, no. 8, pp. 480-484, 1986.

[23] D. W. Cockcroft, D. N. Killian, J. J. Mellon, and F. E. Hargreave, "Bronchial reactivity to inhaled histamine: a method and clinical survey," Clinical Allergy, vol. 7, no. 3, pp. 235-243, 1977.

[24] E. R. McFadden Jr. and I. A. Gilbert, "Exercise-induced asthma," The New England Journal of Medicine, vol. 330, no. 19, pp. 1362-1367, 1994.

[25] J. W. Weiss, T. H. Rossing, E. R. McFadden Jr., and R. H. Ingram, "Relationship between bronchial responsiveness to hyperventilation with cold and methacholine in asthma," Journal of Allergy and Clinical Immunology, vol. 72, no. 2, pp. 140-144, 1983.

[26] S. Redline, I. B. Tager, R. G. Castile, S. T. Weiss, M. Barr, and F. E. Speizer, "Assessment of the usefulness of helium-oxygen maximal expiratory flow curves in epidemiologic studies of lung disease in children," American Review of Respiratory Disease, vol. 136, no. 4, pp. 834-840, 1987.

[27] S. D. Anderson, J. Brannan, J. Spring et al., "A new method for bronchial-provocation testing in asthmatic subjects using a dry powder of mannitol," American Journal of Respiratory and Critical Care Medicine, vol. 156, no. 3, part 1, pp. 758-765, 1997.

[28] G. Rosati, F. E. Hargreave, and E. H. Ramsdale, "Inhalation of adenosine 5'-monophosphate increases methacholine airway responsiveness," Journal of Applied Physiology, vol. 67, no. 2, pp. 792-796, 1989.

[29] R. B. George and M. W. Owens, "Bronchial asthma," Disease-a-Month, vol. 37, no. 3, pp. 142-196, 1991.

[30] P. Berger, J. M. Tunon-De-Lara, J. P. Savineau, and R. Marthan, "Selected contribution: tryptase-induced PAR-2mediated $\mathrm{Ca} 2+$ signaling in human airway smooth muscle cells," Journal of Applied Physiology, vol. 91, no. 2, pp. 995-1003, 2001.

[31] T. Trian, P. O. Girodet, O. Ousova, R. Marthan, J. M. TunonDe-Lara, and P. Berger, "RNA interference decreases PAR-2 expression and function in human airway smooth muscle cells," American Journal of Respiratory Cell and Molecular Biology, vol. 34, no. 1, pp. 49-55, 2006.
[32] M. C. Liu, E. R. Bleecker, L. M. Lichtenstein et al., "Evidence for elevated levels of histamine, prostaglandin D2, and other bronchoconstriction prostaglandins in the airways of subjects with mild asthma," American Review of Respiratory Disease, vol. 142, no. 1, pp. 126-132, 1990.

[33] N. C. Barnes, P. J. Piper, and J. F. Costello, "Comparative effects of inhaled leukotriene C4, leukotriene D4, and histamine in normal human subjects," Thorax, vol. 39, no. 7, pp. 500-504, 1984.

[34] S. E. Dahlen, P. Hedqvist, and P. Westlund, "Mechanisms of leukotriene-induced contractions of guinea pig airways: leukotriene $\mathrm{C} 4$ has a potent direct action whereas leukotriene B4 acts indirectly," Acta Physiologica Scandinavica, vol. 118, no. 4, pp. 393-403, 1983.

[35] S. B. Schwartzberg, S. P. Shelov, and D. Van Praag, "Blood leukotriene levels during the acute asthma attack in children," Prostaglandins Leukotrienes and Medicine, vol. 26, no. 2, pp. 143-155, 1987.

[36] G. Trakada, S. Tsourapis, M. Marangos, and K. Spiropoulos, "Arterial and bronchoalveolar lavage fluid endothelin-1 concentration in asthma," Respiratory Medicine, vol. 94, no. 10, pp. 992-996, 2000.

[37] J. F. Perez-Zoghbi and M. J. Sanderson, "Endothelin-induced contraction of bronchiole and pulmonary arteriole smooth muscle cells is regulated by intracellular Ca2+ oscillations and Ca2+ sensitization," American Journal of Physiology, vol. 293, no. 4, pp. L1000-L1011, 2007.

[38] P. H. Howarth, A. E. Redington, D. R. Springall et al., "Epithelially derived endothelin and nitric oxide in asthma," International Archives of Allergy and Immunology, vol. 107, no. 1-3, pp. 228-230, 1995.

[39] R. Gosens, J. Zaagsma, M. Grootte Bromhaar, A. Nelemans, and H. Meurs, "Acetylcholine: a novel regulator of airway smooth muscle remodelling?" European Journal of Pharmacology, vol. 500, no. 1-3, pp. 193-201, 2004.

[40] I. M. Adcock, M. Peters, C. Gelder, H. Shirasaki, C. R. Brown, and P. J. Barnes, "Increased tachykinin receptor gene expression in asthmatic lung and its modulation by steroids," Journal of Molecular Endocrinology, vol. 11, no. 1, pp. 1-7, 1993.

[41] S. T. Holgate, G. Roberts, H. S. Arshad, P. H. Howarth, and D. E. Davies, "The role of the airway epithelium and its interaction with environmental factors in asthma pathogenesis," Proceedings of the American Thoracic Society, vol. 6, no. 8, pp. 655-659, 2009.

[42] L. Woodman, S. Siddiqui, G. Cruse et al., "Mast cells promote airway smooth muscle cell differentiation via autocrine up-regulation of TGF- $\beta 1$," Journal of Immunology, vol. 181, no. 7, pp. 5001-5007, 2008.

[43] C. L. Armour, P. R. Johnson, M. L. Alfredson, and J. L. Black, "Characterization of contractile prostanoid receptors on human airway smooth muscle," European Journal of Pharmacology, vol. 165, no. 2-3, pp. 215-222, 1989.

[44] J. Xu and N. S. Zhong, "Mechanisms of bronchial hyperresponsiveness: the interaction of endothelin-1 and other cytokines," Respirology, vol. 4, no. 4, pp. 413-417, 1999.

[45] E. Roux, M. Molimard, J. P. Savineau, and R. Marthan, "Muscarinic stimulation of airway smooth muscle cells," General Pharmacology, vol. 31, no. 3, pp. 349-356, 1998.

[46] A. Ben-Jebria, R. Marthan, M. Rossetti, and J. P. Savineau, "Effect of passive sensitization on the mechanical activity of human isolated bronchial smooth muscle induced by substance P, neurokinin A and VIP," British Journal of Pharmacology, vol. 109, no. 1, pp. 131-136, 1993. 
[47] G. F. Joos, "The role of sensory neuropeptides in the pathogenesis of bronchial asthma," Clinical and Experimental Allergy, vol. 19, supplement 1, pp. 9-13, 1989.

[48] E. H. Walters, C. Bevan, R. W. Parrish et al., "Time-dependent effect of prostaglandin E2 inhalation on airway responses to bronchoconstrictor agents in normal subjects," Thorax, vol. 37, no. 6, pp. 438-442, 1982.

[49] P. J. Barnes, "Adrenergic and non-adrenergic, non-cholinergic control of airways," Respiration, vol. 50, no. 2, pp. 9-16, 1986.

[50] C. Davis and M. S. Kannan, "Sympathetic innervation of human tracheal and bronchial smooth muscle," Respiration Physiology, vol. 68, no. 1, pp. 53-61, 1987.

[51] R. J. Pack and P. S. Richardson, "The aminergic innervation of the human bronchus: a light and electron microscopic study," Journal of Anatomy, vol. 138, no. 3, pp. 493-502, 1984.

[52] P. J. Barnes, " $\beta$-adrenergic receptors and their regulation," American Journal of Respiratory and Critical Care Medicine, vol. 152, no. 3, pp. 838-860, 1995.

[53] V. H. van der Velden and A. R. Hulsmann, "Autonomic innervation of human airways: structure, function, and pathophysiology in asthma," NeuroImmunomodulation, vol. 6, no. 3, pp. 145-159, 1999.

[54] A. Laitinen, M. Partanen, A. Hervonen et al., "VIP like immunoreactive nerves in human respiratory tract. Light and electron microscopic study," Histochemistry, vol. 82, no. 4, pp. 313-319, 1985.

[55] A. El-Shazly, P. Berger, P. O. Girodet et al., "Fraktalkine produced by airway smooth muscle cells contributes to mast cell recruitment in asthma," Journal of Immunology, vol. 176, no. 3, pp. 1860-1868, 2006.

[56] L. S. Chambers, J. L. Black, Q. Ge et al., "PAR-2 activation, PGE2, and COX-2 in human asthmatic and nonasthmatic airway smooth muscle cells," American Journal of Physiology, vol. 285, no. 3, pp. L619-L627, 2003.

[57] H. Hakonarson, N. Maskeri, C. Carter, and M. M. Grunstein, "Regulation of $\mathrm{TH} 1$ - and TH2-type cytokine expression and action in atopic asthmatic sensitized airway smooth muscle," Journal of Clinical Investigation, vol. 103, no. 7, pp. 1077-1087, 1999.

[58] J. C. Laporte, P. E. Moore, S. Baraldo et al., "Direct effects of interleukin-13 on signaling pathways for physiological responses in cultured human airway smooth muscle cells," American Journal of Respiratory and Critical Care Medicine, vol. 164, no. 1, pp. 141-148, 2001.

[59] P. R. Johnson, A. J. Ammit, S. M. Carlin, C. L. Armour, G. H. Caughey, and J. L. Black, "Mast cell tryptase potentiates histamine-induced contraction in human sensitized bronchus," European Respiratory Journal, vol. 10, no. 1, pp. 38-43, 1997.

[60] P. Berger, S. J. Compton, M. Molimard et al., "Mast cell tryptase as a mediator of hyperresponsiveness in human isolated bronchi," Clinical and Experimental Allergy, vol. 29, no. 6, pp. 804-812, 1999.

[61] T. Trian, G. Benard, H. Begueret et al., "Bronchial smooth muscle remodeling involves calcium-dependent enhanced mitochondrial biogenesis in asthma," Journal of Experimental Medicine, vol. 204, no. 13, pp. 3173-3181, 2007.

[62] K. Mahn, S. J. Hirst, S. Ying et al., "Diminished sarco/ endoplasmic reticulum $\mathrm{Ca} 2+$ ATPase (SERCA) expression contributes to airway remodelling in bronchial asthma," Proceedings of the National Academy of Sciences of the United States of America, vol. 106, no. 26, pp. 10775-10780, 2009.
[63] V. Sathish, M. A. Thompson, J. P. Bailey, C. M. Pabelick, Y. S. Prakash, and G. C. Sieck, "Effect of proinflammatory cytokines on regulation of sarcoplasmic reticulum $\mathrm{Ca} 2+$ reuptake in human airway smooth muscle," American Journal of Physiology, vol. 297, no. 1, pp. L26-L34, 2009.

[64] D. A. Deshpande, S. Dogan, T. F. Walseth et al., "Modulation of calcium signaling by interleukin-13 in human airway smooth muscle: role of CD38/cyclic adenosine diphosphate ribose pathway," American Journal of Respiratory Cell and Molecular Biology, vol. 31, no. 1, pp. 36-42, 2004.

[65] D. A. Deshpande, T. F. Walseth, R. A. Panettieri, and M. S. Kannan, "CD38/cyclic ADP-ribose-mediated Ca2+ signaling contributes to airway smooth muscle hyper-responsiveness," The Faseb Journal, vol. 17, no. 3, pp. 452-454, 2003.

[66] D. A. Deshpande, T. A. White, S. Dogan, T. F. Walseth, R. A. Panettieri, and M. S. Kannan, "CD38/cyclic ADP-ribose signaling: role in the regulation of calcium homeostasis in airway smooth muscle," American Journal of Physiology, vol. 288, no. 5, pp. L773-L788, 2005.

[67] K. Parameswaran, L. J. Janssen, and P. M. O’Byrne, “Airway hyperresponsiveness and calcium handling by smooth muscle: a "Deeper Look",' Chest, vol. 121, no. 2, pp. 621-624, 2002.

[68] J. P. Savineau and R. Marthan, "Activation properties of chemically skinned fibres from human isolated bronchial smooth muscle," Journal of Physiology, vol. 474, no. 3, pp. 433-438, 1994.

[69] X. Ma, Z. Cheng, H. Kong et al., "Changes in biophysical and biochemical properties of single bronchial smooth muscle cells from asthmatic subjects," American Journal of Physiology, vol. 283, no. 6, pp. L1181-L1189, 2002.

[70] L. Benayoun, A. Druilhe, M. C. Dombret, M. Aubier, and M. Pretolani, "Airway structural alterations selectively associated with severe asthma," American Journal of Respiratory and Critical Care Medicine, vol. 167, no. 10, pp. 1360-1368, 2003.

[71] M. Roth, P. R. Johnson, P. Borger et al., "Dysfunctional interaction of C/EBP $\alpha$ and the glucocorticoid receptor in asthmatic bronchial smooth-muscle cells," The New England Journal of Medicine, vol. 351, no. 6, pp. 560-574, 2004.

[72] P. Borger, M. Tamm, J. L. Black, and M. Roth, "Asthma: is it due to an abnormal airway smooth muscle cell?" American Journal of Respiratory and Critical Care Medicine, vol. 174, no. 4, pp. 367-372, 2006.

[73] H. Marsumoto, L. M. Moir, B. G. Oliver et al., "Comparison of gel contraction mediated by airway smooth muscle cells from patients with and without asthma," Thorax, vol. 62, no. 10, pp. 848-854, 2007.

[74] P. G. Woodruff, G. M. Dolganov, R. E. Ferrando et al., "Hyperplasia of smooth muscle in mild to moderate asthma without changes in cell size or gene expression," American Journal of Respiratory and Critical Care Medicine, vol. 169, no. 9, pp. 1001-1006, 2004.

[75] M. P. Walsh, J. E. Andrea, B. G. Allen, and O. Clement-Chomienne, "Smooth muscle protein kinase C," Canadian Journal of Physiology and Pharmacology, vol. 72, no. 11, pp. 13921399, 1994.

[76] J. P. Savineau and R. Marthan, "Modulation of the calcium sensitivity of the smooth muscle contractile apparatus: molecular mechanisms, pharmacological and pathophysiological implications," Fundamental and Clinical Pharmacology, vol. 11, no. 4, pp. 289-299, 1997.

[77] Y. Chiba and M. Misawa, "The role of RhoA-mediated Ca2+ sensitization of bronchial smooth muscle contraction in 
airway hyperresponsiveness," Journal of Smooth Muscle Research, vol. 40, no. 4-5, pp. 155-167, 2004.

[78] I. Hunter, H. J. Cobban, P. Vandenabeele, D. J. Macewan, and G. F. Nixon, "Tumor necrosis factor- $\alpha$-induced activation of RhoA in airway smooth muscle cells: role in the Ca2+ sensitization of myosin light chain20 phosphorylation," Molecular Pharmacology, vol. 63, no. 3, pp. 714-721, 2003.

[79] Y. Chiba, S. Nakazawa, M. Todoroki, K. Shinozaki, H. Sakai, and M. Misawa, "Interleukin-13 augments bronchial smooth muscle contractility with an Up-regulation of RhoA protein," American Journal of Respiratory Cell and Molecular Biology, vol. 40, no. 2, pp. 159-167, 2009.

[80] N. L. Stephens, W. Li, Y. Wang, and X. Ma, "The contractile apparatus of airway smooth muscle biophysics and biochemistry," American Journal of Respiratory and Critical Care Medicine, vol. 158, no. 5, part 3, pp. S80-S94, 1998.

[81] H. Jiang, K. Rao, A. J. Halayko, W. Kepron, and N. L. Stephens, "Bronchial smooth muscle mechanics of a canine model of allergic airway hyperresponsiveness," Journal of Applied Physiology, vol. 72, no. 1, pp. 39-45, 1992.

[82] C. L. Armour, L. M. Diment, and J. L. Black, "Relationship between smooth muscle volume and contractile response in airway tissue. Isometric versus isotonic measurement," Journal of Pharmacology and Experimental Therapeutics, vol. 245, no. 2, pp. 687-691, 1988.

[83] B. E. McParland, P. T. Macklem, and P. D. Pare, "Airway wall remodeling: friend or foe?" Journal of Applied Physiology, vol. 95, no. 1, pp. 426-434, 2003.

[84] M. G. Tansey, K. Luby-Phelps, K. E. Kamm, and J. T. Stull, "Ca2+-dependent phosphorylation of myosin light chain kinase decreases the $\mathrm{Ca} 2+$ sensitivity of light chain phosphorylation within smooth muscle cells," Journal of Biological Chemistry, vol. 269, no. 13, pp. 9912-9920, 1994.

[85] J. G. Garcia, V. Lazar, L. I. Gilbert-McClain, P. J. Gallagher, and A. D. Verin, "Myosin light chain kinase in endothelium: molecular cloning and regulation," American Journal of Respiratory Cell and Molecular Biology, vol. 16, no. 5, pp. 489-494, 1997.

[86] G. Nino, A. Hu, J. S. Grunstein, and M. M. Grunstein, "Mechanism regulating proasthmatic effects of prolonged homologous $\beta 2$-adrenergic receptor desensitization in airway smooth muscle," American Journal of Physiology, vol. 297, no. 4, pp. L746-L757, 2009.

[87] J. Bonnevier and A. Arner, "Actions downstream of cyclic GMP/protein kinase G can reverse protein kinase C-mediated phosphorylation of CPI-17 and $\mathrm{Ca} 2+$ sensitization in smooth muscle," Journal of Biological Chemistry, vol. 279, no. 28, pp. 28998-29003, 2004.

[88] Y. Nakatani, Y. Nishimura, T. Nishiuma, H. Maeda, and M. Yokoyama, "Tumor necrosis factor- $\alpha$ augments contraction and cytosolic $\mathrm{Ca} 2+$ sensitivity through phospholipase A2 in bovine tracheal smooth muscle," European Journal of Pharmacology, vol. 392, no. 3, pp. 175-182, 2000.

[89] S. Araki, M. Ito, Y. Kureishi et al., "Arachidonic acid-induced $\mathrm{Ca} 2+$ sensitization of smooth muscle contraction through activation of Rho-kinase," Pflugers Archiv, vol. 441, no. 5, pp. 596-603, 2001.

[90] A. P. Somlyo and A. V. Somlyo, "Signal transduction by G-proteins, Rho-kinase and protein phosphatase to smooth muscle and non-muscle myosin II," Journal of Physiology, vol. 522, part 2, pp. 177-185, 2000.

[91] J. M. Chalovich, A. Sen, A. Resetar et al., "Caldesmon: binding to actin and myosin and effects on elementary steps in the ATPase cycle," Acta Physiologica Scandinavica, vol. 164, no. 4, pp. 427-435, 1998.

[92] S. J. Winder and M. P. Walsh, "Smooth muscle calponin. Inhibition of actomysosin MgATPase and regulation by phosphorylation," Journal of Biological Chemistry, vol. 265, no. 17, pp. 10148-10155, 1990.

[93] M. M. Grunstein, H. Veler, X. Shan, J. Larson, J. S. Grunstein, and S. Chuang, "Proasthmatic effects and mechanisms of action of the dust mite allergen, Der p 1, in airway smooth muscle," Journal of Allergy and Clinical Immunology, vol. 116, no. 1, pp. 94-101, 2005.

[94] X. Shan, A. Hu, H. Veler et al., "Regulation of Toll-like receptor 4-induced proasthmatic changes in airway smooth muscle function by opposing actions of ERK1/2 and p38 MAPK signaling," American Journal of Physiology, vol. 291, no. 3, pp. L324-L333, 2006.

[95] T. Kaneko, M. Amano, A. Maeda et al., "Identification of calponin as a novel substrate of Rho-kinase," Biochemical and Biophysical Research Communications, vol. 273, no. 1, pp. 110-116, 2000.

[96] S. Somara and K. N. Bitar, "Phosphorylated HSP27 modulates the association of phosphorylated caldesmon with tropomyosin in colonic smooth muscle," American Journal of Physiology, vol. 291, no. 4, pp. G630-G639, 2006.

[97] F. Li, M. Zhang, F. Hussain et al., "Inhibition of p38 MAPKdependent bronchial contraction after ozone by corticosteroids," European Respiratory Journal, vol. 37, no. 4, pp. 933-942, 2011.

[98] Y. Bosse, E. P. Riesenfeld, P. D. Pare, and C. G. Irvin, “It's not all smooth muscle: non-smooth-muscle elements in control of resistance to airflow," Annual Review of Physiology, vol. 72, pp. 437-462, 2010.

[99] L. Peress, G. Sybrecht, and P. T. Macklem, "The mechanism of increase in total lung capacity during acute asthma," American Journal of Medicine, vol. 61, no. 2, pp. 165-169, 1976.

[100] A. F. Gelb, J. Licuanan, C. M. Shinar, and N. Zamel, "Unsuspected loss of lung elastic recoil in chronic persistent asthma," Chest, vol. 121, no. 3, pp. 715-721, 2002.

[101] H. F. Froeb and J. Mead, "Relative hysteresis of the dead space and lung in vivo," Journal of Applied Physiology, vol. 25, no. 3, pp. 244-248, 1968.

[102] N. Scichilone, S. Permutt, and A. Togias, "The lack of the bronchoprotective and not the bronchodilatory ability of deep inspiration is associated with airway hyperresponsiveness," American Journal of Respiratory and Critical Care Medicine, vol. 163, no. 2, pp. 413-419, 2001.

[103] T. Kapsali, S. Permutt, B. Laube, N. Scichilone, and A. Togias, "Potent bronchoprotective effect of deep inspiration and its absence in asthma," Journal of Applied Physiology, vol. 89, no. 2, pp. 711-720, 2000.

[104] P. Gayrard, J. Orehek, C. Grimaud, and J. Charpin, "Bronchoconstrictor effects of a deep inspiration in patients with asthma," American Review of Respiratory Disease, vol. 111, no. 4, pp. 433-439, 1975.

[105] R. Marthan and A. J. Woolcock, "Is a myogenic response involved in deep inspiration-induced bronchoconstriction in asthmatics?" American Review of Respiratory Disease, vol. 140, no. 5, pp. 1354-1358, 1989.

[106] T. K. Lim, S. M. Ang, T. H. Rossing, E. P. Ingenito, and R. H. Ingram, "The effects of deep inhalation on maximal expiratory flow during intensive treatment of spontaneous asthmatic episodes," American Review of Respiratory Disease, vol. 140, no. 2 I, pp. 340-343, 1989. 
[107] R. K. Lambert and P. D. Pare, "Lung parenchymal shear modulus, airway wall remodeling, and bronchial hyperresponsiveness," Journal of Applied Physiology, vol. 83, no. 1, pp. 140-147, 1997.

[108] P. T. Macklem, "A theoretical analysis of the effect of airway smooth muscle load on airway narrowing," American Journal of Respiratory and Critical Care Medicine, vol. 153, no. 1, pp. 83-89, 1996.

[109] P. D. Pare and T. R. Bai, "The consequences of chronic allergic inflammation," Thorax, vol. 50, no. 4, pp. 328-332, 1995.

[110] J. J. Fredberg, D. Inouye, B. Miller et al., "Airway smooth muscle, tidal stretches, and dynamically determined contractile states," American Journal of Respiratory and Critical Care Medicine, vol. 156, no. 6, pp. 1752-1759, 1997.

[111] J. J. Fredberg, "Frozen objects: small airways, big breaths, and asthma," Journal of Allergy and Clinical Immunology, vol. 106, no. 4, pp. 615-624, 2000.

[112] A. M. Bramley, C. R. Roberts, and R. R. Schellenberg, "Collagenase increases shortening of human bronchial smooth muscle in vitro," American Journal of Respiratory and Critical Care Medicine, vol. 152, no. 5, part 1, pp. 1513-1517, 1995.

[113] R. A. Meiss, "Influence of intercellular tissue connections on airway muscle mechanics," Journal of Applied Physiology, vol. 86, no. 1, pp. 5-15, 1999.

[114] J. W. Wilson, X. Li, and M. C. Pain, "The lack of distensibility of asthmatic airways," American Review of Respiratory Disease, vol. 148, no. 3, pp. 806-809, 1993.

[115] G. Damera, O. Tliba, and R. A. Panettieri, "Airway smooth muscle as an immunomodulatory cell," Pulmonary Pharmacology and Therapeutics, vol. 22, no. 5, pp. 353-359, 2009.

[116] S. J. Hirst, "Regulation of airway smooth muscle cell immunomodulatory function: role in asthma," Respiratory Physiology and Neurobiology, vol. 137, no. 2-3, pp. 309-326, 2003.

[117] H. Hakonarson, C. Kim, R. Whelan, D. Campbell, and M. M. Grunstein, "Bi-directional activation between human airway smooth muscle cells and T lymphocytes: role in induction of altered airway responsiveness," Journal of Immunology, vol. 166, no. 1, pp. 293-303, 2001.

[118] A. L. Lazaar, S. M. Albelda, J. M. Pilewski, B. Brennan, E. Pure, and R. A. Panettieri, "T lymphocytes adhere to airway smooth muscle cells via integrins and CD44 and induce smooth muscle cell DNA synthesis," Journal of Experimental Medicine, vol. 180, no. 3, pp. 807-816, 1994.

[119] J. K. Burgess, S. Carlin, R. A. Pack et al., "Detection and characterization of OX40 ligand expression in human airway smooth muscle cells: a possible role in asthma?" Journal of Allergy and Clinical Immunology, vol. 113, no. 4, pp. 683-689, 2004.

[120] A. L. Lazaar, H. E. Reitz, R. A. Panettieri, S. P. Peters, and E. Pure, "Antigen receptor-stimulated peripheral blood and bronchoalveolar lavage-derived T Cells induce MHC class II and ICAM-1 expression on human airway smooth muscle," American Journal of Respiratory Cell and Molecular Biology, vol. 16, no. 1, pp. 38-45, 1997.

[121] M. B. Sukkar, S. Xie, N. M. Khorasani et al., "Toll-like receptor 2, 3, and 4 expression and function in human airway smooth muscle," Journal of Allergy and Clinical Immunology, vol. 118, no. 3, pp. 641-648, 2006.

[122] R. Saunders, A. Sutcliffe, D. Kaur et al., "Airway smooth muscle chemokine receptor expression and function in asthma," Clinical and Experimental Allergy, vol. 39, no. 11, pp. 1684-1692, 2009.

[123] Y. Chang, L. Al-Alwan, P. A. Risse et al., "TH17 cytokines induce human airway smooth muscle cell migration," Journal of Allergy and Clinical Immunology, vol. 127, no. 4, pp. 1046-1053, 2011.

[124] J. L. Pype, L. J. Dupont, P. Menten et al., "Expression of monocyte chemotactic protein (MCP)-1, MCP-2, and MCP-3 by human airway smooth-muscle cells: modulation by corticosteroids and T-helper 2 cytokines," American Journal of Respiratory Cell and Molecular Biology, vol. 21, no. 4, pp. 528-536, 1999.

[125] M. John, S. J. Hirst, P. J. Jose et al., "Human airway smooth muscle cells express and release RANTES in response to T helper 1 cytokines: regulation by $\mathrm{T}$ helper 2 cytokines and corticosteroids," Journal of Immunology, vol. 158, no. 4, pp. 1841-1847, 1997.

[126] O. Ghaffar, Q. Hamid, P. M. Renzi et al., "Constitutive and cytokine-stimulated expression of eotaxin by human airway smooth muscle cells," American Journal of Respiratory and Critical Care Medicine, vol. 159, no. 6, pp. 1933-1942, 1999.

[127] D. S. Faffe, T. Whitehead, P. E. Moore et al., "IL-13 and IL-4 promote TARC release in human airway smooth muscle cells: role of IL-4 receptor genotype," American Journal of Physiology, vol. 285, no. 4, pp. L907-L914, 2003.

[128] D. Kaur, R. Saunders, P. Berger et al., "Airway smooth muscle and mast cell-derived CC chemokine ligand 19 mediate airway smooth muscle migration in asthma," American Journal of Respiratory and Critical Care Medicine, vol. 174, no. 11, pp. 1179-1188, 2006.

[129] M. L. Watson, S. P. Grix, N. J. Jordan et al., "Interleukin 8 and monocyte chemoattractant protein 1 production by cultured human airway smooth muscle cells," Cytokine, vol. 10, no. 5, pp. 346-352, 1998.

[130] C. E. Brightling, A. J. Ammit, D. Kaur et al., "The CXCL10/ CXCR3 axis mediates human lung mast cell migration to asthmatic airway smooth muscle," American Journal of Respiratory and Critical Care Medicine, vol. 171, no. 10, pp. 1103-1108, 2005.

[131] J. A. Elias, Y. Wu, T. Zheng, and R. Panettieri, "Cytokine- and virus-stimulated airway smooth muscle cells produce IL-11 and other IL-6-type cytokines," American Journal of Physiology, vol. 273, no. 3, part 1, pp. L648-L655, 1997.

[132] J. K. Burgess, P. R. Johnson, Q. Ge et al., "Expression of connective tissue growth factor in asthmatic airway smooth muscle cells," American Journal of Respiratory and Critical Care Medicine, vol. 167, no. 1, pp. 71-77, 2003.

[133] M. P. Hallsworth, C. P. Soh, C. H. Twort, T. H. Lee, and S. J. Hirst, "Cultured human airway smooth muscle cells stimulated by interleukin- $1 \beta$ enhance eosinophil survival," American Journal of Respiratory Cell and Molecular Biology, vol. 19, no. 6, pp. 910-919, 1998.

[134] O. Kassel, F. Schmidlin, C. Duvernelle, B. Gasser, G. Massard, and N. Frossard, "Human bronchial smooth muscle cells in culture produce stem cell factor," European Respiratory Journal, vol. 13, no. 5, pp. 951-954, 1999.

[135] S. McKay, J. C. de Jongste, P. R. Saxena, and H. S. Sharma, "Angiotensin II induces hypertrophy of human airway smooth muscle cells: expression of transcription factors and transforming growth factor- $\beta 1$," American Journal of Respiratory Cell and Molecular Biology, vol. 18, no. 6, pp. 823-833, 1998.

[136] A. J. Knox, L. Corbett, J. Stocks, E. Holland, Y. M. Zhu, and L. Pang, "Human airway smooth muscle cells secrete vascular endothelial growth factor: up-regulation by bradykinin via a protein kinase C and prostanoid-dependent mechanism," The Faseb Journal, vol. 15, no. 13, pp. 2480-2488, 2001. 
[137] P. R. Johnson, J. L. Black, S. Carlin, Q. Ge, and P. A. Underwood, "The production of extracellular matrix proteins by human passively sensitized airway smooth-muscle cells in culture: the effect of beclomethasone," American Journal of Respiratory and Critical Care Medicine, vol. 162, no. 6, pp. 2145-2151, 2000.

[138] S. R. Elshaw, N. Henderson, A. J. Knox, S. A. Watson, D. J. Buttle, and S. R. Johnson, "Matrix metalloproteinase expression and activity in human airway smooth muscle cells," British Journal of Pharmacology, vol. 142, no. 8, pp. 1318-1324, 2004.

[139] B. B. Araujo, M. Dolhnikoff, L. F. Silva et al., "Extracellular matrix components and regulators in the airway smooth muscle in asthma," European Respiratory Journal, vol. 32, no. 1, pp. 61-69, 2008.

[140] C. E. Brightling, P. Bradding, F. A. Symon, S. T. Holgate, A. J. Wardlaw, and I. D. Pavord, "Mast-cell infiltration of airway smooth muscle in asthma," The New England Journal of Medicine, vol. 346, no. 22, pp. 1699-1705, 2002.

[141] T. Koshino, S. Teshima, N. Fukushima et al., "Identification of basophils by immunohistochemistry in the airways of post-mortem cases of fatal asthma," Clinical and Experimental Allergy, vol. 23, no. 11, pp. 919-925, 1993.

[142] K. Amin, C. Janson, G. Boman, and P. Venge, "The extracellular deposition of mast cell products is increased in hypertrophic airways smooth muscles in allergic asthma but not in nonallergic asthma," Allergy, vol. 60, no. 10, pp. 1241-1247, 2005.

[143] N. G. Carroll, S. Mutavdzic, and A. L. James, "Distribution and degranulation of airway mast cells in normal and asthmatic subjects," European Respiratory Journal, vol. 19, no. 5, pp. 879-885, 2002.

[144] P. Berger, P. O. Girodet, H. Begueret et al., "Tryptase-stimulated human airway smooth muscle cells induce cytokine synthesis and mast cell chemotaxis," The Faseb Journal, vol. 17, no. 14, pp. 2139-2141, 2003.

[145] S. Siddiqui, V. Mistry, C. Doe et al., "Airway hyperresponsiveness is dissociated from airway wall structural remodeling," Journal of Allergy and Clinical Immunology, vol. 122, no. 2, pp. 335.e1-341.e3, 2008.

[146] S. K. Saha, M. A. Berry, D. Parker et al., "Increased sputum and bronchial biopsy IL-13 expression in severe asthma," Journal of Allergy and Clinical Immunology, vol. 121, no. 3, pp. 685-691, 2008.

[147] D. Kaur, R. Saunders, F. Hollins et al., "Mast cell fibroblastoid differentiation mediated by airway smooth muscle in asthma," Journal of Immunology, vol. 185, no. 10, pp. 6105-6114, 2010.

[148] A. J. Ammit, S. S. Bekir, P. R. Johnson, J. M. Hughes, C. L. Armour, and J. L. Black, "Mast cell numbers are increased in the smooth muscle of human sensitized isolated bronchi," American Journal of Respiratory and Critical Care Medicine, vol. 155, no. 3, pp. 1123-1129, 1997.

[149] P. Berger, A. F. Walls, R. Marthan, and J. M. Tunon-de-Lara, "Immunoglobulin E-induced passive sensitization of human airways: an immunohistochemical study," American Journal of Respiratory and Critical Care Medicine, vol. 157, no. 2, pp. 610-616, 1998.

[150] P. Berger, J. Lavallee, R. Rouiller, F. Laurent, R. Marthan, and J. M. Tunon-De-Lara, "Assessment of bronchial inflammation using an automated cell recognition system based on colour analysis," European Respiratory Journal, vol. 14, no. 6, pp. 1394-1402, 1999.
[151] P. Berger, C. N' guyen, M. Buckley, E. Scotto-Gomez, R. Marthan, and J. M. Tunon-De-Lara, "Passive sensitization of human airways induces mast cell degranulation and release of tryptase," Allergy, vol. 57, no. 7, pp. 592-599, 2002.

[152] P. Berger, F. Laurent, H. Begueret et al., "Structure and function of small airways in smokers: relationship between air trapping at CT and airway inflammation," Radiology, vol. 228, no. 1, pp. 85-94, 2003.

[153] P. Berger, P. O. Girodet, and J. M. Tunon-de-Lara, "Mast cell myositis: a new feature of allergic asthma?" Allergy, vol. 60, no. 10, pp. 1238-1240, 2005.

[154] M. Berry, A. Morgan, D. E. Shaw et al., "Pathological features and inhaled corticosteroid response of eosinophilic and non-eosinophilic asthma," Thorax, vol. 62, no. 12, pp. 1043-1049, 2007.

[155] A. Sutcliffe, D. Kaur, S. Page et al., "Mast cell migration to Th2 stimulated airway smooth muscle from asthmatics," Thorax, vol. 61, no. 8, pp. 657-662, 2006.

[156] W. Yang, D. Kaur, Y. Okayama et al., "Human lung mast cells adhere to human airway smooth muscle, in part, via tumor suppressor in lung cancer-1," Journal of Immunology, vol. 176, no. 2, pp. 1238-1243, 2006.

[157] F. Hollins, D. Kaur, W. Yang et al., "Human airway smooth muscle promotes human lung mast cell survival, proliferation, and constitutive activation: cooperative roles for CADM1, stem cell factor, and IL-6," Journal of Immunology, vol. 181, no. 4, pp. 2772-2780, 2008.

[158] R. J. Carter and P. Bradding, "The role of mast cells in the structural alterations of the airways as a potential mechanism in the pathogenesis of severe asthma," Current Pharmaceutical Design, vol. 17, no. 7, pp. 685-698, 2011.

[159] C. E. Brightling, F. A. Symon, S. T. Holgate, A. J. Wardlaw, I. D. Pavord, and P. Bradding, "Interleukin-4 and -13 expression is co-localized to mast cells within the airway smooth muscle in asthma," Clinical and Experimental Allergy, vol. 33, no. 12, pp. 1711-1716, 2003.

[160] P. Bradding, A. F. Walls, and S. T. Holgate, "The role of the mast cell in the pathophysiology of asthma," Journal of Allergy and Clinical Immunology, vol. 117, no. 6, pp. 1277-1284, 2006.

[161] D. Kaur, F. Hollins, R. Saunders et al., "Airway smooth muscle proliferation and survival is not modulated by mast cells," Clinical and Experimental Allergy, vol. 40, no. 2, pp. 279-288, 2010.

[162] E. B. Thangam, R. T. Venkatesha, A. K. Zaidi et al., "Airway smooth muscle cells enhance C3a-induced mast cell degranulation following cell-cell contact," The Faseb Journal, vol. 19, no. 7, pp. 798-800, 2005.

[163] J. F. Molinari, M. Scuri, W. R. Moore, J. Clark, R. Tanaka, and W. M. Abraham, "Inhaled tryptase causes bronchoconstriction in sheep via histamine release," American Journal of Respiratory and Critical Care Medicine, vol. 154, no. 3, part 1, pp. 649-653, 1996.

[164] P. Berger, D. W. Perng, H. Thabrew et al., "Tryptase and agonists of PAR-2 induce the proliferation of human airway smooth muscle cells," Journal of Applied Physiology, vol. 91, no. 3, pp. 1372-1379, 2001.

[165] R. Saunders, A. Sutcliffe, L. Woodman et al., "The airway smooth muscle CCR3/CCL11 axis is inhibited by mast cells," Allergy, vol. 63, no. 9, pp. 1148-1155, 2008.

[166] D. Ramos-Barbon, J. F. Presley, Q. A. Hamid, E. D. Fixman, and J. G. Martin, "Antigen-specific CD4+ T cells drive airway smooth muscle remodeling in experimental asthma," Journal of Clinical Investigation, vol. 115, no. 6, pp. 1580-1589, 2005. 
[167] A. L. Lazaar, M. I. Plotnick, U. Kucich et al., "Mast cell chymase modifies cell-matrix interactions and inhibits mitogeninduced proliferation of human airway smooth muscle cells," Journal of Immunology, vol. 169, no. 2, pp. 1014-1020, 2002.

[168] H. Veler, A. Hu, S. Fatma et al., "Superantigen presentation by airway smooth muscle to CD4+ T lymphocytes elicits reciprocal proasthmatic changes in airway function," Journal of Immunology, vol. 178, no. 6, pp. 3627-3636, 2007.

[169] A. L. Lazaar, Y. Amrani, J. Hsu et al., "CD40-mediated signal transduction in human airway smooth muscle," Journal of Immunology, vol. 161, no. 6, pp. 3120-3127, 1998.

[170] J. K. Burgess, A. E. Blake, S. Boustany et al., "CD40 and OX40 ligand are increased on stimulated asthmatic airway smooth muscle," Journal of Allergy and Clinical Immunology, vol. 115, no. 2, pp. 302-308, 2005.

[171] D. I. Krimmer, M. Loseli, J. M. Hughes et al., "CD40 and OX40 ligand are differentially regulated on asthmatic airway smooth muscle," Allergy, vol. 64, no. 7, pp. 1074-1082, 2009.

[172] S. Siddiqui, V. Mistry, C. Doe, S. Stinson, M. Foster, and C. Brightling, "Airway wall expression of OX40/OX40L and Lnterleukin-4 in asthma," Chest, vol. 137, no. 4, pp. 797-804, 2010.

[173] Y. Xu and G. Song, "The role of CD40-CD154 interaction in cell immunoregulation," Journal of Biomedical Science, vol. 11, no. 4, pp. 426-438, 2004.

[174] T. Fujita, N. Ukyo, T. Hori, and T. Uchiyama, "Functional characterization of OX40 expressed on human CD8+ T cells," Immunology Letters, vol. 106, no. 1, pp. 27-33, 2006.

[175] M. Ebina, T. Takahashi, T. Chiba, and M. Motomiya, "Cellular hypertrophy and hyperplasia of airway smooth muscles underlying bronchial asthma: a 3-D morphometric study," American Review of Respiratory Disease, vol. 148, no. 3, pp. 720-726, 1993.

[176] P. O. Girodet, A. Ozier, I. Bara, J. M. Tunon De Lara, R. Marthan, and P. Berger, "Airway remodeling in asthma: new mechanisms and potential for pharmacological intervention," Pharmacology and Therapeutics, vol. 130, no. 3, pp. 325-337, 2011.

[177] A. Coutts, G. Chen, N. Stephens et al., "Release of biologically active TGF- $\beta$ from airway smooth muscle cells induces autocrine synthesis of collagen," American Journal of Physiology, vol. 280, no. 5, pp. L999-L1008, 2001.

[178] R. Halwani, S. Al-Muhsen, H. Al-Jahdali, and Q. Hamid, "Role of transforming growth factor- $\beta$ in airway remodeling in asthma," American Journal of Respiratory Cell and Molecular Biology, vol. 44, no. 2, pp. 127-133, 2011.

[179] P. R. A. Johnson, M. Roth, M. Tamm et al., "Airway smooth muscle cell proliferation is increased in asthma," American Journal of Respiratory and Critical Care Medicine, vol. 164, no. 3, pp. 474-477, 2001.

[180] J. K. Burgess, H. L. Jin, Q. I. Ge et al., "Dual ERK and phosphatidylinositol 3-kinase pathways control airway smooth muscle proliferation: differences in asthma," Journal of Cellular Physiology, vol. 216, no. 3, pp. 673-679, 2008.

[181] M. Hassan, T. Jo, P. A. Risse et al., "Airway smooth muscle remodeling is a dynamic process in severe long-standing asthma," Journal of Allergy and Clinical Immunology, vol. 125, no. 5, pp. 1037-1045.e3, 2010.

[182] O. Tliba and R. A. Panettieri Jr., "Noncontractile functions of airway smooth muscle cells in asthma," Annual Review of Physiology, vol. 71, pp. 509-535, 2009.

[183] K. Mahn, O. O. Ojo, G. Chadwick, P. I. Aaronson, J. P. T. Ward, and T. H. Lee, "Ca2+ homeostasis and structural and functional remodelling of airway smooth muscle in asthma," Thorax, vol. 65, no. 6, pp. 547-552, 2010.

[184] D. Zhou, X. Zheng, L. Wang et al., "Expression and effects of cardiotrophin-1 (CT-1) in human airway smooth muscle cells," British Journal of Pharmacology, vol. 140, no. 7, pp. 1237-1244, 2003.

[185] R. McWhinnie, D. V. Pechkovsky, D. Zhou et al., "Endothelin-1 induces hypertrophy and inhibits apoptosis in human airway smooth muscle cells," American Journal of Physiology, vol. 292, no. 1, pp. L278-L286, 2007.

[186] R. Halwani, J. Al-Abri, M. Beland et al., "CC and CXC chemokines induce airway smooth muscle proliferation and survival," Journal of Immunology, vol. 186, no. 7, pp. 4156-4163, 2011.

[187] A. M. Freyer, S. R. Johnson, and I. P. Hall, "Effects of growth factors and extracellular matrix on survival of human airway smooth muscle cells," American Journal of Respiratory Cell and Molecular Biology, vol. 25, no. 5, pp. 569-576, 2001.

[188] K. Solarewicz-Madejek, T. M. Basinski, R. Crameri et al., "T cells and eosinophils in bronchial smooth muscle cell death in asthma," Clinical and Experimental Allergy, vol. 39, no. 6, pp. 845-855, 2009.

[189] K. J. Hamann, J. E. Vieira, A. J. Halayko et al., "Fas crosslinking induces apoptosis in human airway smooth muscle cells," American Journal of Physiology, vol. 278, no. 3, pp. L618-L624, 2000.

[190] S. Salinthone, M. Ba, L. Hanson, J. L. Martin, A. J. Halayko, and W. T. Gerthoffer, "Overexpression of human Hsp27 inhibits serum-induced proliferation in airway smooth muscle myocytes and confers resistance to hydrogen peroxide cytotoxicity," American Journal of Physiology, vol. 293, no. 5, pp. L1194-L1207, 2007.

[191] U. Oltmanns, M. B. Sukkar, S. Xie, M. John, and K. F. Chung, "Induction of human airway smooth muscle apoptosis by neutrophils and neutrophil elastase," American Journal of Respiratory Cell and Molecular Biology, vol. 32, no. 4, pp. 334-341, 2005.

[192] M. L. D’ Antoni, C. Torregiani, P. Ferraro et al., "Effects of decorin and biglycan on human airway smooth muscle cell proliferation and apoptosis," American Journal of Physiology, vol. 294, no. 4, pp. L764-L771, 2008.

[193] H. J. Patel, M. G. Belvisi, D. Bishop-Bailey, M. H. Yacoub, and J. A. Mitchell, "Activation of peroxisome proliferatoractivated receptors in human airway smooth muscle cells has a superior anti-inflammatory profile to corticosteroids: relevance for chronic obstructive pulmonary disease therapy," Journal of Immunology, vol. 170, no. 5, pp. 2663-2669, 2003.

[194] S. Ghavami, M. M. Mutawe, K. Hauff et al., "Statin-triggered cell death in primary human lung mesenchymal cells involves p53-PUMA and release of Smac and Omi but not cytochrome c," Biochimica et Biophysica Acta, vol. 1803, no. 4, pp. 452-467, 2010.

[195] N. M. Robertson, J. G. Zangrilli, A. Steplewski et al., "Differential expression of TRAIL and TRAIL receptors in allergic asthmatics following segmental antigen challenge: evidence for a role of TRAIL in eosinophil survival," Journal of Immunology, vol. 169, no. 10, pp. 5986-5996, 2002.

[196] L. Benayoun, S. Letuve, A. Druilhe et al., "Regulation of peroxisome proliferator-activated receptor $\gamma$ expression in human asthmatic airways: relationship with proliferation, apoptosis, and airway remodeling," American Journal of Respiratory and Critical Care Medicine, vol. 164, no. 8, part 1, pp. 1487-1494, 2001. 
[197] W. T. Gerthoffer, "Migration of airway smooth muscle cells," Proceedings of the American Thoracic Society, vol. 5, no. 1, pp. 97-105, 2008.

[198] M. J. Gizycki, E. Adelroth, A. V. Rogers, P. M. O’Byrne, and P. K. Jeffery, "Myofibroblast involvement in the allergeninduced late response in mild atopic asthma," American Journal of Respiratory Cell and Molecular Biology, vol. 16, no. 6, pp. 664-673, 1997.

[199] D. W. Powell, R. C. Mifflin, J. D. Valentich, S. E. Crowe, J. I. Saada, and A. B. West, "Myofibroblasts. I. Paracrine cells important in health and disease," American Journal of Physiology, vol. 277, no. 1, part 1, pp. C1-C19, 1999.

[200] S. J. Hirst, J. G. Martin, J. V. Bonacci et al., "Proliferative aspects of airway smooth muscle," Journal of Allergy and Clinical Immunology, vol. 114, no. 2, supplement, pp. S2-S17, 2004.

[201] M. Iwano, D. Plieth, T. M. Danoff, C. Xue, H. Okada, and E. G. Neilson, "Evidence that fibroblasts derive from epithelium during tissue fibrosis," Journal of Clinical Investigation, vol. 110, no. 3, pp. 341-350, 2002.

[202] R. Kalluri and E. G. Neilson, "Epithelial-mesenchymal transition and its implications for fibrosis," Journal of Clinical Investigation, vol. 112, no. 12, pp. 1776-1784, 2003.

[203] B. C. Willis, R. M. DuBois, and Z. Borok, "Epithelial origin of myofibroblasts during fibrosis in the lung," Proceedings of the American Thoracic Society, vol. 3, no. 4, pp. 377-382, 2006.

[204] M. Schmidt, G. Sun, M. A. Stacey, L. Mori, and S. Mattoli, "Identification of circulating fibrocytes as precursors of bronchial myofibroblasts in asthma," Journal of Immunology, vol. 171, no. 1, pp. 380-389, 2003.

[205] C. H. Wang, C. D. Huang, H. C. Lin et al., "Increased circulating fibrocytes in asthma with chronic airflow obstruction," American Journal of Respiratory and Critical Care Medicine, vol. 178, no. 6, pp. 583-591, 2008.

[206] R. Saunders, S. Siddiqui, D. Kaur et al., "Fibrocyte localization to the airway smooth muscle is a feature of asthma," Journal of Allergy and Clinical Immunology, vol. 123, no. 2, pp. 376-384, 2009.

[207] K. Nihlberg, K. Larsen, A. Hultgardh-Nilsson et al., "Tissue fibrocytes in patients with mild asthma: a possible link to thickness of reticular basement membrane?" Respiratory Research, vol. 7, p. 50, 2006.

[208] Y. L. Ye, H. T. Wu, C. F. Lin et al., "Dermatophagoides pteronyssinus 2 regulates nerve growth factor release to induce airway inflammation via a reactive oxygen species-dependent pathway," American Journal of Physiology, vol. 300, no. 2, pp. L216-L224, 2011.

[209] R. A. Reilkoff, R. Bucala, and E. L. Herzog, "Fibrocytes: emerging effector cells in chronic inflammation," Nature Reviews Immunology, vol. 11, no. 6, pp. 427-435, 2011.

[210] R. M. Strieter, B. N. Gomperts, and M. P. Keane, "The role of CXC chemokines in pulmonary fibrosis," Journal of Clinical Investigation, vol. 117, no. 3, pp. 549-556, 2007.

[211] S. J. Hirst, P. J. Barnes, and C. H. Twort, "PDGF isoforminduced proliferation and receptor expression in human cultured airway smooth muscle cells," American Journal of Physiology, vol. 270, no. 3, part 1, pp. L415-L428, 1996.

[212] K. M. Hawker, P. R. Johnson, J. M. Hughes, and J. L. Black, "Interleukin-4 inhibits mitogen-induced proliferation of human airway smooth muscle cells in culture," American Journal of Physiology, vol. 275, no. 3, part 1, pp. L469-L477, 1998.

[213] R. A. Panettieri Jr., R. G. Goldie, P. J. Rigby, A. J. Eszterhas, and D. W. P. Hay, "Endothelin-1-induced potentiation of human airway smooth muscle proliferation: an ETA receptor-mediated phenomenon," British Journal of Pharmacology, vol. 118, no. 1, pp. 191-197, 1996.

[214] A. G. Stewart, P. R. Tomlinson, D. J. Fernandes, J. W. Wilson, and T. Harris, "Tumor necrosis factor $\alpha$ modulates mitogenic responses of human cultured airway smooth muscle," American Journal of Respiratory Cell and Molecular Biology, vol. 12, no. 1, pp. 110-119, 1995.

[215] M. D. Cohen, V. Ciocca, and R. A. Panettieri Jr., "TGF- $\beta 1$ modulates human airway smooth-muscle cell proliferation induced by mitogens," American Journal of Respiratory Cell and Molecular Biology, vol. 16, no. 1, pp. 85-90, 1997.

[216] S. Xie, M. B. Sukkar, R. Issa, N. M. Khorasani, and K. F. Chung, "Mechanisms of induction of airway smooth muscle hyperplasia by transforming growth factor- $\beta$," American Journal of Physiology, vol. 293, no. 1, pp. L245-L253, 2007.

[217] K. Maruno, A. Absood, and S. I. Said, "VIP inhibits basal and histamine-stimulated proliferation of human airway smooth muscle cells," American Journal of Physiology, vol. 268, no. 6, part 1, pp. L1047-L1051, 1995.

[218] P. R. Tomlinson, J. W. Wilson, and A. G. Stewart, "Inhibition by salbutamol of the proliferation of human airway smooth muscle cells grown in culture," British Journal of Pharmacology, vol. 111, no. 2, pp. 641-647, 1994.

[219] V. Capra, A. Habib, M. R. Accomazzo et al., "Thromboxane prostanoid receptor in human airway smooth muscle cells: a relevant role in proliferation," European Journal of Pharmacology, vol. 474, no. 2-3, pp. 149-159, 2003.

[220] A. J. Ammit, A. T. Hastie, L. C. Edsall et al., "Sphingosine 1-phosphate modulates human airway smooth muscle cell functions that promote inflammation and airway remodeling in asthma," The Faseb Journal, vol. 15, no. 7, pp. 1212-1214, 2001.

[221] S. Ravasi, S. Citro, B. Viviani, V. Capra, and G. E. Rovati, "CysLT1 receptor-induced human airway smooth muscle cells proliferation requires ROS generation, EGF receptortransactivation and ERK1/2 phosphorylation," Respiratory Research, vol. 7, article 42, 2006.

[222] R. A. Panettieri, I. P. Hall, C. S. Maki, and R. K. Murray, “ $\alpha$ Thrombin increases cytosolic calcium and induces human airway smooth muscle cell proliferation," American Journal of Respiratory Cell and Molecular Biology, vol. 13, no. 2, pp. 205-216, 1995.

[223] C. D. Huang, H. H. Chen, C. H. Wang et al., "Human neutrophil-derived elastase induces airway smooth muscle cell proliferation," Life Sciences, vol. 74, no. 20, pp. 2479-2492, 2004.

[224] N. A. Hasaneen, S. Zucker, J. Cao, C. Chiarelli, R. A. Panettieri, and H. D. Foda, "Cyclic mechanical strain-induced proliferation and migration of human airway smooth muscle cells: role of EMMPRIN and MMPs," The Faseb Journal, vol. 19, no. 11, pp. 1507-1509, 2005.

[225] T. T. Nguyen, J. P. Ward, and S. J. Hirst, " $\beta 1$-integrins mediate enhancement of airway smooth muscle proliferation by collagen and fibronectin," American Journal of Respiratory and Critical Care Medicine, vol. 171, no. 3, pp. 217-223, 2005.

[226] H. C. Pandya, V. A. Snetkov, C. H. Twort, J. P. Ward, and S. J. Hirst, "Oxygen regulates mitogen-stimulated proliferation of fetal human airway smooth muscle cells," American Journal of Physiology, vol. 283, no. 6, pp. L1220-L1230, 2002.

[227] P. G. Smith, K. E. Janiga, and M. C. Bruce, "Strain increases airway smooth muscle cell proliferation," American Journal of Respiratory Cell and Molecular Biology, vol. 10, no. 1, pp. 85-90, 1994. 
[228] B. Aravamudan, M. Thompson, C. Pabelick et al., "Brain derived neurotrophic factor induces proliferation of human airway smooth muscle cells ," Journal of Cellular and Molecular Medicine. In press.

[229] E. A. Goncharova, C. K. Billington, C. Irani et al., "Cyclic AMP-mobilizing agents and glucocorticoids modulate human smooth muscle cell migration," American Journal of Respiratory Cell and Molecular Biology, vol. 29, no. 1, pp. 19-27, 2003.

[230] J. C. Hedges, M. A. Dechert, I. A. Yamboliev et al., "A role for p38(MAPK)/HSP27 pathway in smooth muscle cell migration," Journal of Biological Chemistry, vol. 274, no. 34, pp. 24211-24219, 1999.

[231] N. Takeda, Y. Sumi, D. Prefontaine et al., "Epitheliumderived chemokines induce airway smooth muscle cell migration," Clinical and Experimental Allergy, vol. 39, no. 7, pp. 1018-1026, 2009.

[232] P. Joubert, S. Lajoie-Kadoch, I. Labonte et al., "CCR3 expression and function in asthmatic airway smooth muscle cells," Journal of Immunology, vol. 175, no. 4, pp. 2702-2708, 2005.

[233] K. Parameswaran, K. Radford, J. Zuo, L. J. Janssen, P. M. O' Byrne, and P. G. Cox, "Extracellular matrix regulates human airway smooth muscle cell migration," European Respiratory Journal, vol. 24, no. 4, pp. 545-551, 2004.

[234] I. Ito, E. D. Fixman, K. Asai et al., "Platelet-derived growth factor and transforming growth factor- $\beta$ modulate the expression of matrix metalloproteinases and migratory function of human airway smooth muscle cells," Clinical and Experimental Allergy, vol. 39, no. 9, pp. 1370-1380, 2009.

[235] N. Henderson, L. J. Markwick, S. R. Elshaw, A. M. Freyer, A. J. Knox, and S. R. Johnson, "Collagen I and thrombin activate MMP-2 by MMP-14-dependent and -independent pathways: implications for airway smooth muscle migration," American Journal of Physiology, vol. 292, no. 4, pp. L1030 L1038, 2007.

[236] E. A. Goncharova, A. V. Vorotnikov, E. O. Gracheva et al., "Activation of p38 MAP-kinase and caldesmon phosphorylation are essential for urokinase-induced human smooth muscle cell migration," Biological Chemistry, vol. 383, no. 1, pp. 115-126, 2002.

[237] A. J. Halayko, S. Kartha, G. L. Stelmack et al., "Phophatidylinositol-3 kinase/mammalian target of rapamycin/p70 S6K regulates contractile protein accumulation in airway myocyte differentiation," American Journal of Respiratory Cell and Molecular Biology, vol. 31, no. 3, pp. 266-275, 2004.

[238] A. M. Goldsmith, J. K. Bentley, L. Zhou et al., "Transforming growth factor- $\beta$ induces airway smooth muscle hypertrophy," American Journal of Respiratory Cell and Molecular Biology, vol. 34, no. 2, pp. 247-254, 2006.

[239] J. S. Mohamed, M. A. Lopez, and A. M. Boriek, "Mechanical stretch up-regulates microRNA-26a and induces human airway smooth muscle hypertrophy by suppressing glycogen synthase kinase-3 $\gamma$," Journal of Biological Chemistry, vol. 285, no. 38, pp. 29336-29347, 2010.

[240] M. Meyer, W. Schillinger, B. Pieske et al., "Alterations of sarcoplasmic reticulum proteins in failing human dilated cardiomyopathy," Circulation, vol. 92, no. 4, pp. 778-784, 1995.

[241] J. K. Bentley and M. B. Hershenson, "Airway smooth mus-cle growth in asthma: proliferation, hypertrophy, and migration," Proceedings of the American Thoracic Society, vol. 5, no. 1, pp. 89-96, 2008.

[242] L. Zhou, A. M. Goldsmith, J. K. Bentley et al., "4E-binding protein phosphorylation and eukaryotic initiation factor- $4 \mathrm{E}$ release are required for airway smooth muscle hypertrophy,"
American Journal of Respiratory Cell and Molecular Biology, vol. 33, no. 2, pp. 195-202, 2005.

[243] H. Deng, M. B. Hershenson, J. Lei et al., "p70 ribosomal S6 kinase is required for airway smooth muscle cell size enlargement but not increased contractile protein expression," American Journal of Respiratory Cell and Molecular Biology, vol. 42, no. 6, pp. 744-752, 2010.

[244] H. Deng, G. A. Dokshin, J. Lei et al., "Inhibition of glycogen synthase kinase-3 $\beta$ is sufficient for airway smooth muscle hypertrophy," Journal of Biological Chemistry, vol. 283, no. 15, pp. 10198-10207, 2008.

[245] A. Laitinen, A. Altraja, M. Kampe, M. Linden, I. Virtanen, and L. A. Laitinen, "Tenascin is increased in airway basement membrane of asthmatics and decreased by an inhaled steroid," American Journal of Respiratory and Critical Care Medicine, vol. 156, no. 3, part 1, pp. 951-958, 1997.

[246] C. R. Roberts, "Remodelling of the extracellular matrix in asthma: proteoglycan synthesis and degradation," Canadian Respiratory Journal, vol. 5, no. 1, pp. 48-50, 1998.

[247] J. Bousquet, P. Chanez, J. Y. Lacoste et al., "Asthma: a disease remodeling the airways," Allergy, vol. 47, no. 1, pp. 3-11, 1992.

[248] A. Torrego, M. Hew, T. Oates, M. Sukkar, and F. C. Kian, "Expression and activation of TGF- $\beta$ isoforms in acute allergeninduced remodelling in asthma," Thorax, vol. 62, no. 4, pp. 307-313, 2007.

[249] P. Flood-Page, A. Menzies-Gow, S. Phipps et al., "Anti-IL-5 treatment reduces deposition of ECM proteins in the bronchial subepithelial basement membrane of mild atopic asthmatics," Journal of Clinical Investigation, vol. 112, no. 7, pp. 1029-1036, 2003.

[250] L. A. Laitinen, A. Laitinen, A. Altraja et al., "Bronchial biopsy findings in intermittent or "early" asthma," Journal of Allergy and Clinical Immunology, vol. 98, no. 5, part 2, pp. S33-S40, 1996.

[251] S. Gabbrielli, S. Di Lollo, N. Stanflin, and P. Romagnoli, "Myofibroblast and elastic and collagen fiber hyperplasia in the bronchial mucosa: a possible basis for the progressive irreversibility of airway obstruction in chronic asthma," Pathologica, vol. 86, no. 2, pp. 157-160, 1994.

[252] T. R. Bai, J. Cooper, T. Koelmeyer, P. D. Pare, and T. D. Weir, "The effect of age and duration of disease on airway structure in fatal asthma," American Journal of Respiratory and Critical Care Medicine, vol. 162, no. 2, part 1, pp. 663-669, 2000.

[253] P. R. Johnson, J. K. Burgess, P. A. Underwood et al., "Extracellular matrix proteins modulate asthmatic airway smooth muscle cell proliferation via an autocrine mechanism," Journal of Allergy and Clinical Immunology, vol. 113, no. 4, pp. 690-696, 2004.

[254] J. K. Burgess, C. Ceresa, S. R. Johnson et al., "Tissue and matrix influences on airway smooth muscle function," Pulmonary Pharmacology and Therapeutics, vol. 22, no. 5, pp. 379-387, 2009.

[255] S. J. Hirst, C. H. Twort, and T. H. Lee, "Differential effects of extracellular matrix proteins on human airway smooth muscle cell proliferation and phenotype," American Journal of Respiratory Cell and Molecular Biology, vol. 23, no. 3, pp. 335-344, 2000.

[256] Q. Peng, D. Lai, T. T. Nguyen, V. Chan, T. Matsuda, and S. J. Hirst, "Multiple $\beta 1$ integrins mediate enhancement of human airway smooth muscle cytokine secretion by fibronectin and type I collagen," Journal of Immunology, vol. 174, no. 4, pp. 2258-2264, 2005. 
[257] T. Tran, K. D. McNeill, W. T. Gerthoffer, H. Unruh, and A. J. Halayko, "Endogenous laminin is required for human airway smooth muscle cell maturation," Respiratory Research, vol. 7, article 117, 2006.

[258] M. Lederlin, A. Ozier, M. Montaudon et al., "Airway remodeling in a mouse asthma model assessed by in-vivo respiratory-gated micro-computed tomography," European Radiology, vol. 20, no. 1, pp. 128-137, 2010. 


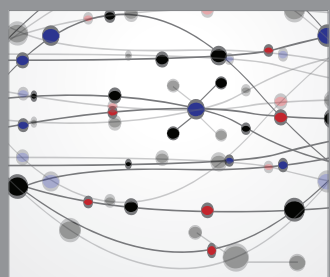

The Scientific World Journal
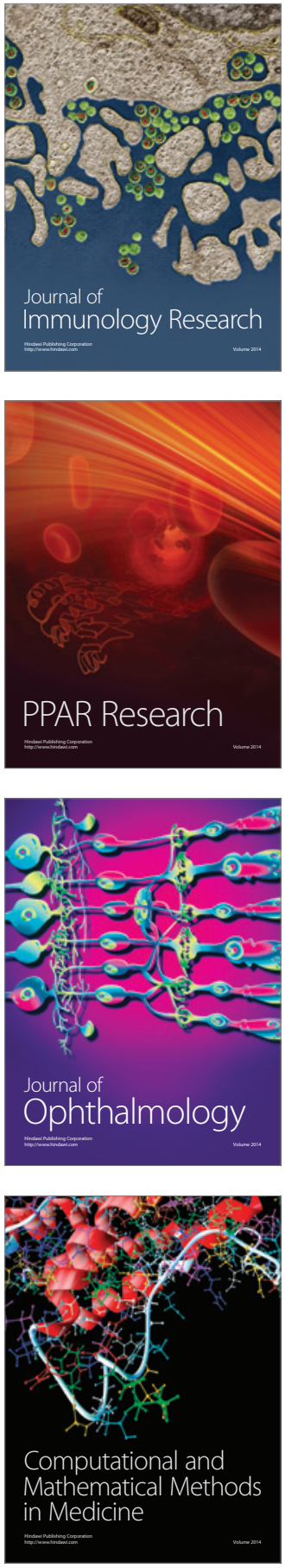

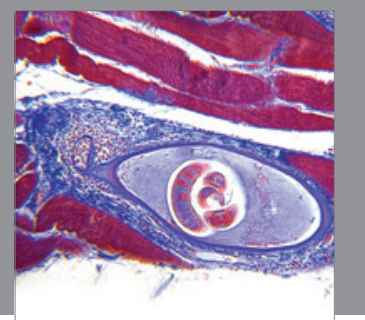

Gastroenterology

Research and Practice
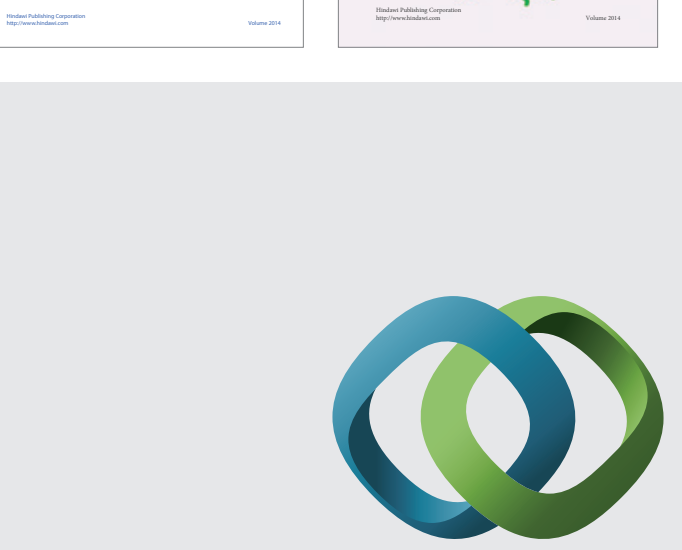

\section{Hindawi}

Submit your manuscripts at

http://www.hindawi.com
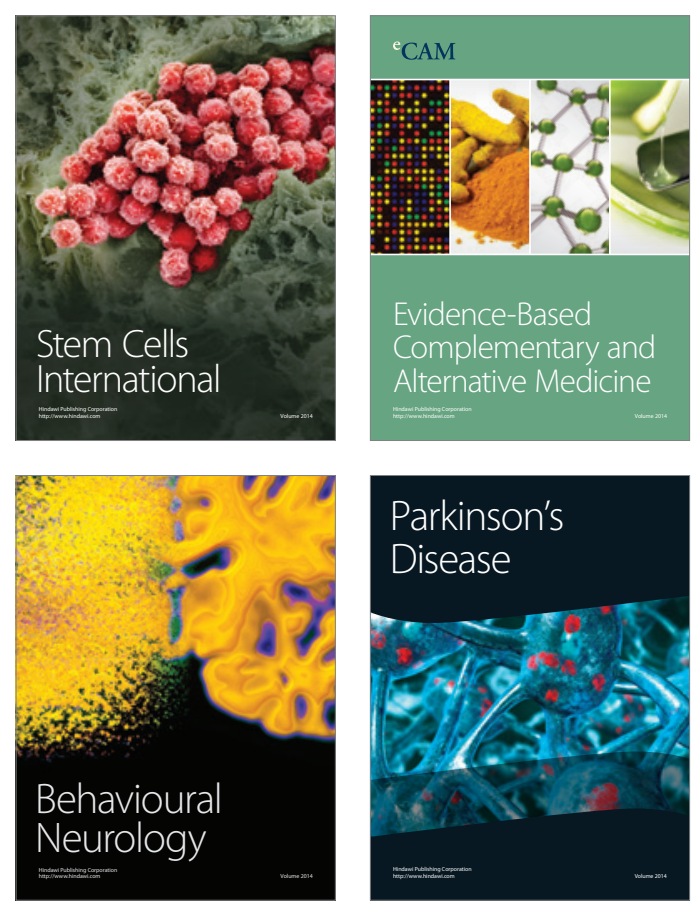

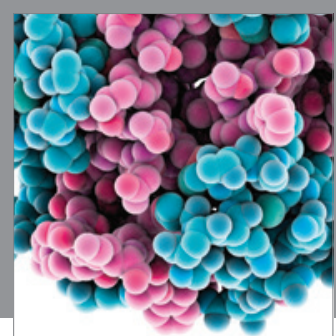

Journal of
Diabetes Research

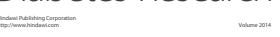

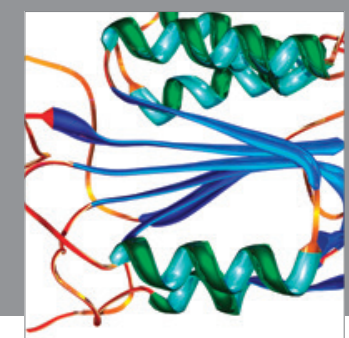

Disease Markers
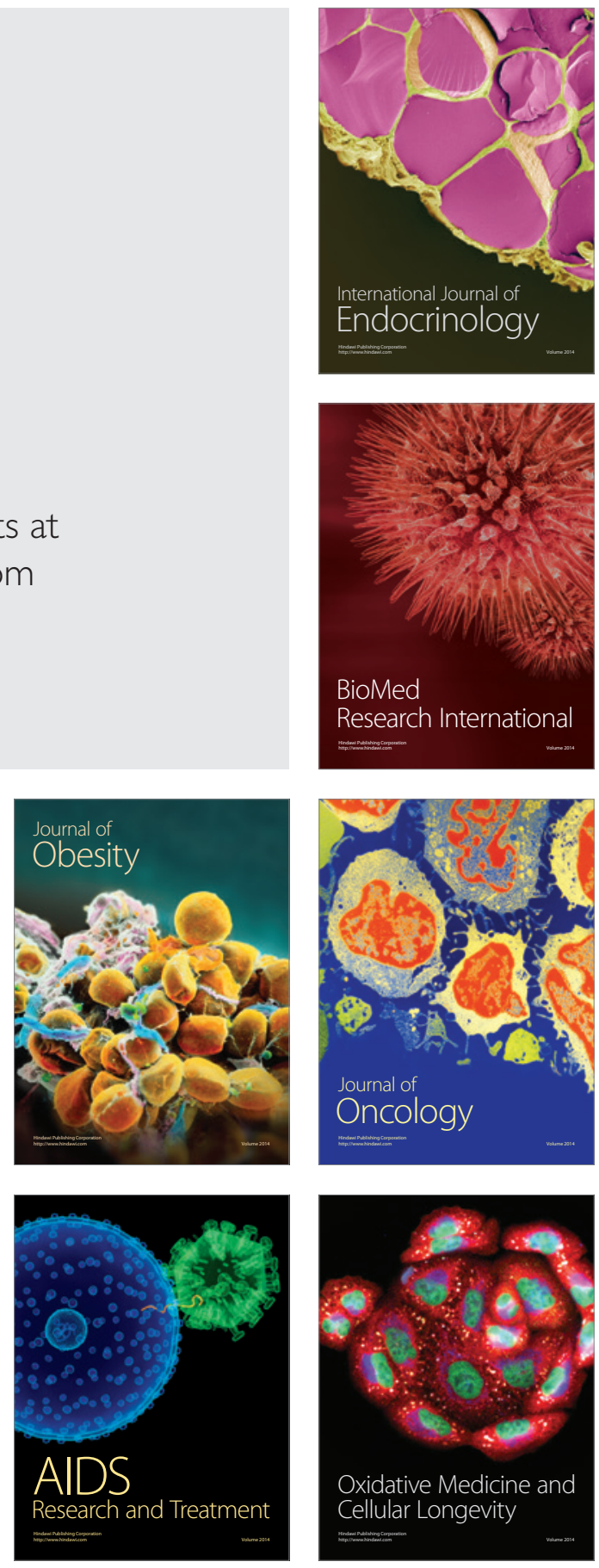